\title{
DATING OF THE HOMINID (HOMO NEANDERTHALENSIS) REMAINS ACCUMULATION FROM EL SIDRÓN CAVE (PILOÑA, ASTURIAS, NORTH SPAIN): AN EXAMPLE OF A MULTI-METHODOLOGICAL APPROACH TO THE DATING OF UPPER PLEISTOCENE SITES
}

T. de TORRES, ${ }^{1}$ J. E. ORTIZ, ${ }^{1}$ R. GRÜN, ${ }^{2}$ S. EGGINS,${ }^{2}$ H. VALLADAS,${ }^{3}$ N. MERCIER,,${ }^{3}$ N. TISNÉRAT-LABORDE, ${ }^{3}$ R. JULIÁ, ${ }^{4}$ V. SOLER, ${ }^{5}$ E. MARTÍNEZ, ${ }^{6}$ S. SÁNCHEZ-MORAL, ${ }^{7}$ J. C. CAÑAVERAS,${ }^{8}$ J. LARIO, ${ }^{9}$ E. BADAL,,${ }^{10}$ C. LALUEZA-FOX ${ }^{11}$ A. ROSAS, ${ }^{12}$ D. SANTAMARÍA, ${ }^{13}$ M. de la RASILLA ${ }^{13} \dagger$ and J. FORTEA ${ }^{13 \dagger}$

\footnotetext{
${ }^{1}$ Laboratorio de Estratigrafia Biomolecular, ETSIM, Universidad Politécnica de Madrid, cl Rios Rosas 21, 28003 Madrid, Spain

${ }^{2}$ Research School of Earth Sciences, Australian National University, Canberra ACT 0200, Australia

${ }^{3}$ LSCE APSL, CEA-CNRS-UVSQ, Avenue de la Terrasse, 91198 Gif Sur Yvette Cedex, France

${ }^{4}$ Institut Jaume Almera de Ciencies de la Terra, CSIC, c/ Luis Solé i Sabaris s/n, 08048 Barcelona, Spain ${ }^{5}$ Estación Volcanológica de Canarias, IPNA-CSIC, Avda. Astrofísico Francisco Sánchez 3, 38206 La Laguna, Tenerife, Spain

${ }^{6}$ Departamento de Geomorfología Interna, Facultad de Geología, Universidad de Oviedo, c/ Jesús Arias de Velasco s/n, 33005 Oviedo, Spain

${ }^{7}$ Departamento de Geologia, MNCN-CSIC, cl José Gutiérrez Abascal 2, 28006 Madrid, Spain

${ }^{8}$ Departamento de Ciencias de la Tierra y del Medio Ambiente, Facultad de Ciencias, Universidad de Alicante, AP. Correos 99, 03080 Alicante, Spain

${ }^{9}$ Departamento de Ciencias Analíticas, Facultad de Ciencias, UNED, Paseo Senda del Rey 9, 28040 Madrid, Spain ${ }^{10}$ Departamento de Prehistoria y Arqueología, Facultad de $G^{a}$ e Historia, Universidad de Valencia, Avda. Blasco Ibánez 28, 46010 Valencia, Spain

${ }^{11}$ Institut de Biologia Evolutiva, UPF-CSIC, c/ Dr. Aiguader 88, 08003, Barcelona, Spain

${ }^{12}$ Departamento de Paleobiología, MNCN-CSIC, cl José Gutierrez Abascal 2, 28006 Madrid, Spain

${ }^{13}$ Departamento de Historia, Facultad de $G^{a}$ e Historia, Universidad de Oviedo, cl Teniente Alfonso Martínez s/n, 33011 Oviedo, Spain
}

The age of Neanderthal remains and associated sediments from El Sidrón cave has been obtained through different dating methods $\left({ }^{14} \mathrm{CAMS}\right.$, U/TH, OSL, ESR and AAR) and samples (charcoal debris, bone, tooth dentine, stalagmitic flowstone, carbonate-rich sediments, sedimentary quartz grains, tooth enamel and land snail shells). Detrital Th contamination rendered $T h / U$ dating analyses of flowstone unreliable. Recent ${ }^{14} \mathrm{C}$ contamination produced spurious age-values from charcoal samples as well as from inadequately pretreated tooth samples. Most consistent ${ }^{14} \mathrm{C}$ dates are grouped into two series: one between 35 and $40 \mathrm{ka}$ and the other between 48 and $49 \mathrm{ka}$. Most ESR and AAR samples yielded concordant ages, ranging between 39 and $45 \mathrm{ka}$; OSL dating results permitted adequate bracketing of the sedimentary layer that contained the human remains. Our results emphasize the value of multi-dating approaches for the establishment of reliable chronologies of human remains. 


\section{INTRODUCTION}

The El Sidrón cave site constitutes a paradigm of paleoanthropological findings. In 1994, members of a speleological group discovered the first human remains on the floor of a gallery of the cave. These remains ended up in the neighbouring Guardia Civil (a police corps) presidio which sent the bones to the National Forensic Institution, where the experts immediately realized that they were not of modern humans but much older ones. This initial mistake can be understood in historical terms, because during the Spanish Civil War (1936-1939), the cave was used as a guerilla refuge. In fact, at the entrance of the cave there is a tomb in the shadow of an ancient chestnut tree. Today flowers decorate the grave, which has become the focus of local pilgrimage.

J. L. Prieto from the National Forensic Institute sent a bone sample to the University of Arizona for dating, but not enough collagen was found for AMS dating. The bones were subsequently studied by B. Vandermeersch and M. D. Garralda who ascribed these remains to Homo sapiens with very archaic characteristics (published in local press). However, Rosas and Aguirre (1999) attributed the remains to Homo neanderthalensis, a view which was reconfirmed by others (Egocheaga et al. 2000; Prieto et al. 2001). Since 2000, fieldwork, including archaeological excavation, prospecting and geophysics, has been conducted by J. Fortea and M. de la Rasilla in order to obtain more palaeoanthropological and archaeological material and to discover their autochthonous position (Fortea et al. 2003; Rosas et al. 2006).

The aim of this paper is not only focused on the dating of El Sidrón cave hominid remains, but also on a discussion of the value of results obtained through the use of different dating techniques which were applied on fossil remains and sediment samples.

\section{GEOGRAPHICAL AND GEOLOGICAL SETTINGS}

El Sidrón cave $\left(5^{\circ} 19^{\prime} 34^{\prime \prime} \mathrm{W} ; 43^{\circ} 23^{\prime} 07^{\prime \prime} \mathrm{N}\right.$; elevation $\left.167 \mathrm{~m}\right)$ is located in the vicinity of Borines, a small village in Asturias (northern Spain) (Fig. 1). The wider area consists of Jurassic and Cretaceous limestones and Tertiary outcrops. In the north and south, border quartzites, black shales and limestones of Palaeozoic age appear (Gervilla et al. 1978; Martínez 1989). The area was affected by alpine compression generating NNE-SSW and NW-SE fault systems, which favoured the installation of a palaeofluvial drainage network. During the Pleistocene a distensive phase produced an E-W fault system.

El Sidrón cave is developed in Tertiary carbonate conglomerates alternating with fine- to medium-grained sandstones, dipping $20-30^{\circ}$ to the north. Dissolution processes preferentially affect conglomerates. The dip of strata and the fault systems explain both the geometry of the karst system and the morphology of individual galleries. The cave axis (Fig. 2) consists of a $600 \mathrm{~m}$ long NNW-SSE phreatic tube with an E-W oriented central segment of $200 \mathrm{~m}$ length, following the strike of the bedding plane. Faults are visible on the ceiling of the galleries. Less developed galleries orthogonal to the main gallery are also conditioned by the fault system. One of them, the Galería del Osario (GO, Ossuary Gallery), houses the archaeological and palaeontological site. Formerly, the GO was presumably open air, connected through a sink hole, but nowadays this entrance is sealed with collapsed blocks and finer grained sediments.

\section{Sedimentology and stratigraphy}

The excavations performed in 2000 started in section 3, squares E, F, G and H-8 (Fig. 2), with the aim of obtaining the widest stratigraphical section possible between the GO walls $\mathrm{E}$ and $\mathrm{W}$ 

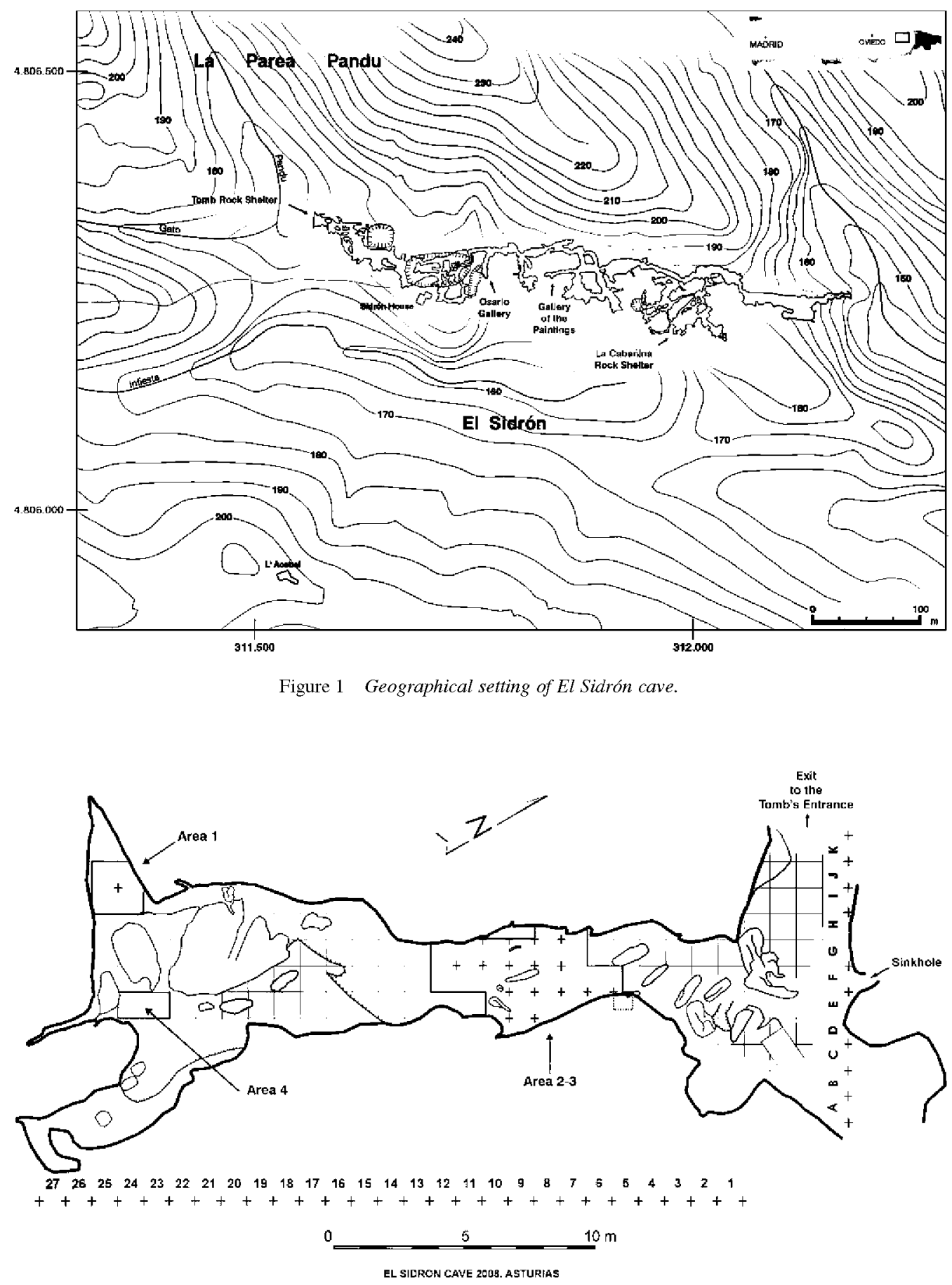

Figure 2 Map of the excavated areas in El Sidrón cave (Ossuary Gallery - GO). 


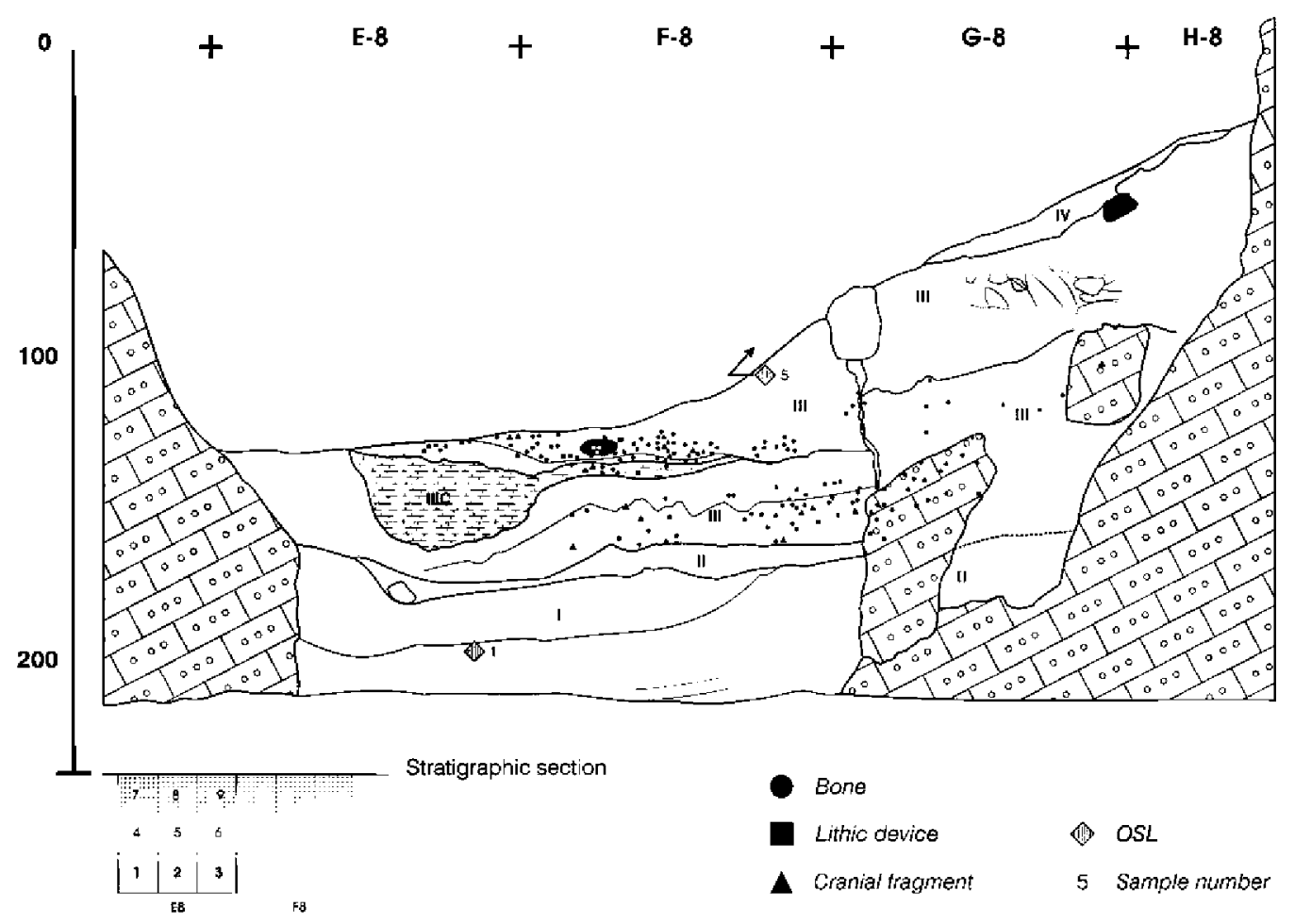

Figure 3 Stratigraphic section in E-H/8 ( $\alpha$ ), with the localizations of SID-22 (OSL 1) and SID 23 (OSL 5) samples (the latter respect the coordinates $X$ and $Z$, but $Y$ is located $105 \mathrm{~cm}$ to the south in the stratigraphic section $\delta$ between Units III/IV - see also Figs 4 and 5). Lithic and bone remains are projected in the section.

(Fig. 3). During the following years, the excavation works continued by means of $33 \mathrm{~cm}$ wide strips towards $\mathrm{N}$ and S. Drawings and photographs of every new section obtained were taken, and projection points were determined (as $\mathrm{x}, \mathrm{y}, \mathrm{z}$ ) for archaeological and anthropological material, as well as mineral or organic elements, to be dated in each section. This gave something like a stratigraphical tomography with more than 14 sections separated every $33 \mathrm{~cm}$, containing all the relevant information properly documented. There is no room here to include all these sections; Figure 3 is shown as an example. Complementarily, Figure 4 shows the horizontal position of some of the elements that have been dated.

In short, four major sedimentary units have been recognized in the infill of the central part of the GO - sections 2, 3 and 5 (Fig. 2). They can be summarized, from bottom to top, as follows (Fig. 5):

0 : Unit of massive mud located at the bottom of the column. No clear sedimentary structures can be distinguished. Provisionally they appear to be sediments deposited through a low energy outflow.

I. Unit of laminated fine sands and mud, with cross-stratification. It includes low-intensity fluvial-karstic material with a relative increase in energy at the top.

II: Unit of poorly sorted gravels, sands and mud. Until now, it has represented the lower limit of the fossiliferous units. The fluvial-karstic materials originated from a high energy event and are clearly erosive in nature. 

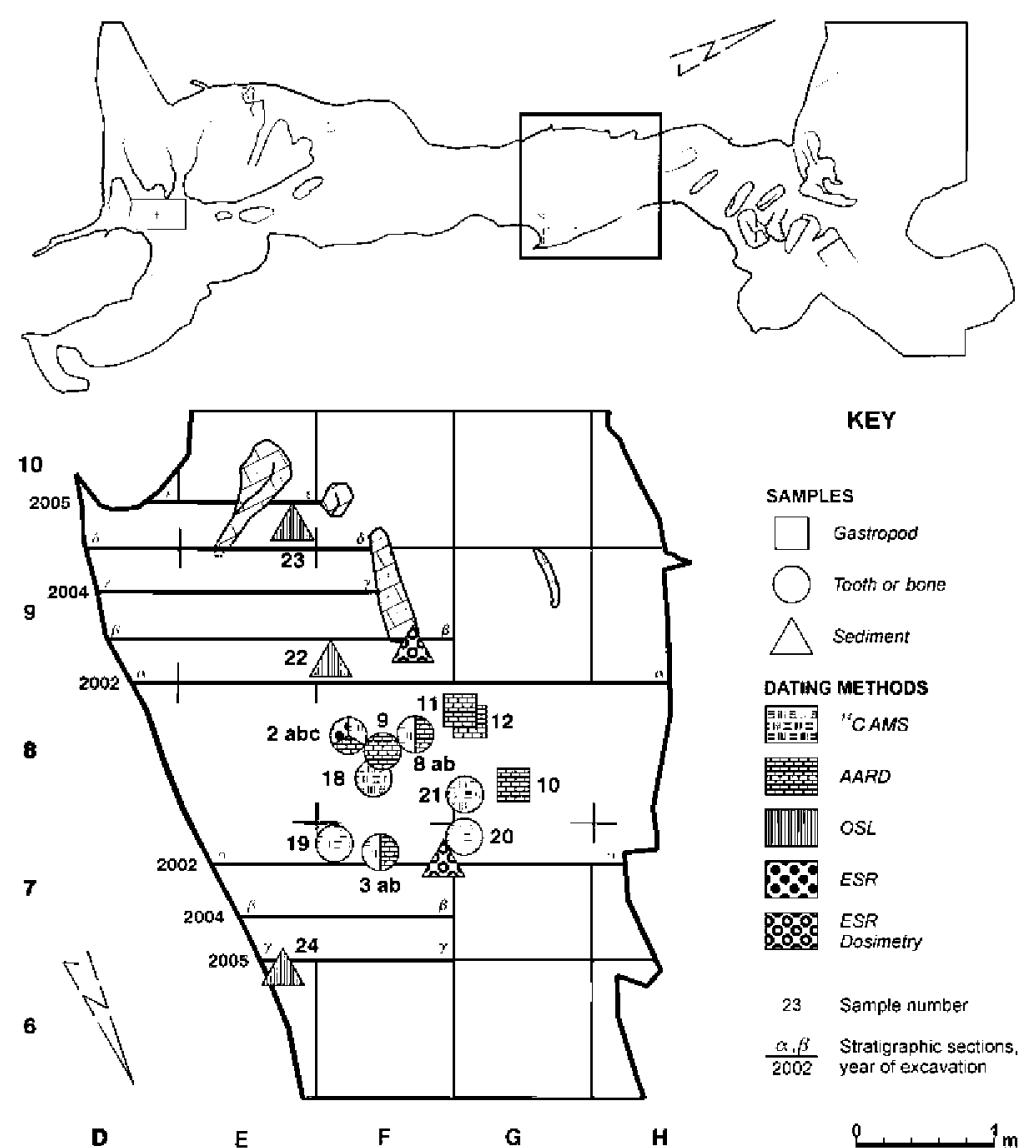

SAMPLES

$\square$ Gastropod

(C) Tooth or bone

$\triangle$ sectiment

DATING METHODS

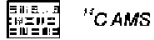

籜 AARD

IIII||T|| OSL

Ee ESR

$\begin{array}{ll}\text { D0\% } & \text { ESR } \\ 000 \text { Dosimetry }\end{array}$

23

Semple number

$\alpha, \beta$ Stratigraphic sections,

D

E

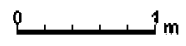

Figure 4 Horizontal projection of the different elements dated in the Ossuary Gallery - GO.

III: Unit of massive clays with dispersed levels of gravels, sands and silts. Interbedded silts and fine sands showing water-scape structures are common. At the base, this unit is very similar to the previous one and, in general, the grain decreases upward. In the western part of the gallery, the grain size of the unit is also coarser, with a predominance of pebble and gravel deposits. A prominent feature is the existence of calcareous crusts (IIIc) on the top of the unit.

IV: Unit of massive mud with some interbedded sands. These sediments formed in a very low energy fluvial-karstic environment, and correspond to the final infill episode in the gallery which can be regarded as still in progress.

In general, the unit that holds most of the bone and lithic remains (III) consists of a massive deposit (debris flow) composed of a chaotic mixture of gravels, mud and water. Therefore, the arrival and the accumulation of the remains (bones) must have happened immediately after the entry of the previously mentioned gravel deposit (Unit II), and would have been associated with the same high-energy event. The data accumulated so far indicate that they were probably dragged down from a higher level, where very little or no activity had taken place until that time due to the position above the water table as a result of the confinement of the external fluvial network channels. 


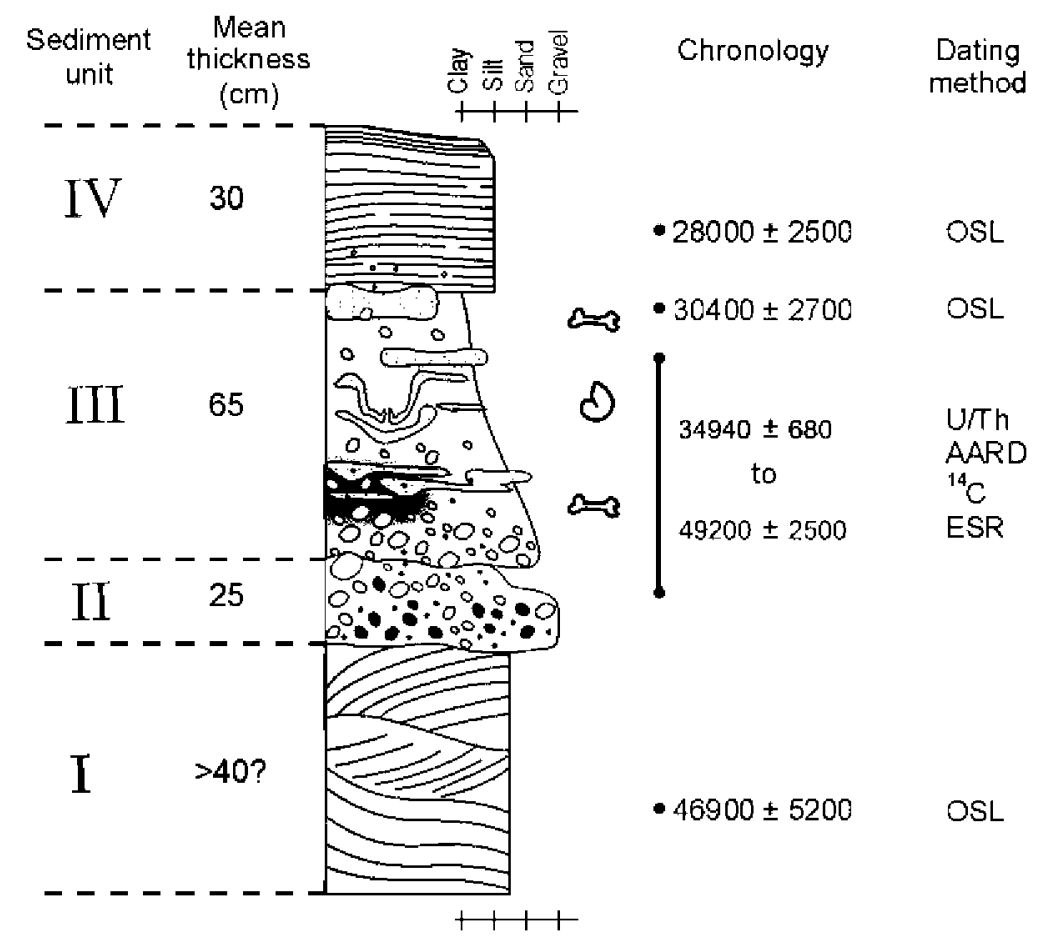

Figure 5 Synthetic section of the Ossuary Gallery with the different stratigraphic units differentiated and the position of samples taken for dating. The calculated ages and dating methods are given on the right (U/Th method did not work properly). Sedimentary units: I: Interlayered sands and silts with cross-bedding; II: Coarse sands and gravels; III: Clays and fine sands with early deformation (slump) structures. Presence of artefacts and bones; IV: Laminated silts and sands. The ${ }^{14} \mathrm{C}$ dates are uncalibrated and $B P$.

A mass of loose material situated in that higher cavity/gallery went downstream into the cave in a single occurrence of mud seepage due to a collapse and/or a storm event. The outcome was the arrival of a mass of pebbles, sands, bones and clays that would accumulate over a substratum (rock or previous sediments) and/or remain wedged in the subvertical fissures that are characteristic of the western part of the gallery. The particular layout of the remains and of the unit containing them suggest the possibility that they entered the gallery through one of the shafts located in the vertical section of bore I (squares G/H-9/10) and currently blocked up by a filler of clays (Sánchez-Moral et al. 2007).

Next, an intermittent entry of archaeological and anthropological remains occurred while the sequence upper part was being formed (Unit IV). In addition, displacement towards the main gallery and to the lower phreatic stratum took place in the case of some materials previously deposited in lines D and E (next to the east wall) due, on the one hand, to a fluvial-karstic flow coming from the south of the Ossuary Gallery and, on the other, to a stream sink located in squares $\mathrm{E}-\mathrm{F} / 9$.

\section{The palaeoanthropological record}

The Neanderthal human group displays a set of well-defined derived features, e.g., apomorphies (Wolpoff 1980; Trinkaus 1988; Tattersall and Schwartz 1998; Rosas 2001; Condemi 2003; 


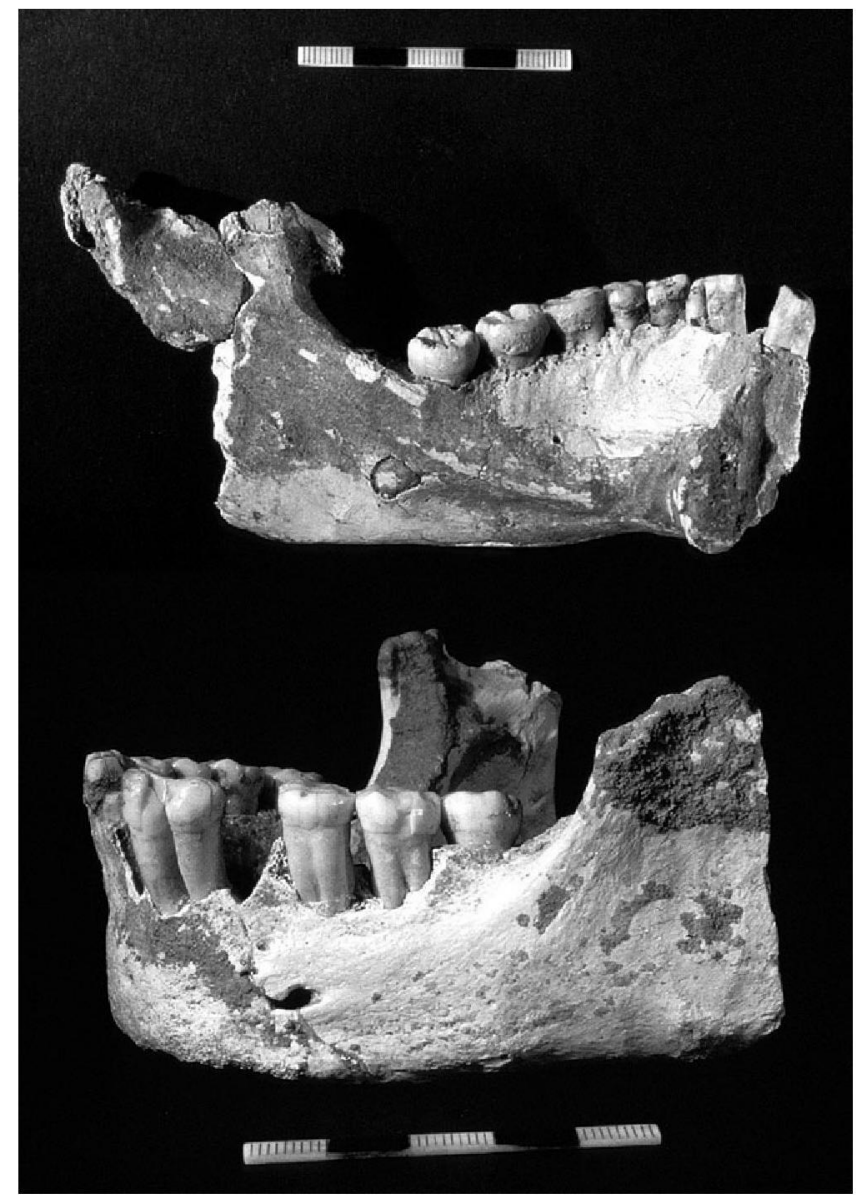

Figure 6 Mandibles I and II of adult hominids from El Sidrón cave (Photo J. Fortea).

among others). Thus, the human species represented at El Sidrón cave correspond to Homo neanderthalensis (Rosas and Aguirre 1999; Rosas et al. 2006, 2008). The El Sidrón teeth are large, with crenulated enamel and accessory cusps. Neanderthal lineage incisor features (Bermúdez de Castro 1993) observed in the sample include shovel-shaping, marked labial convexity, and strongly developed lingual tubercles. On the premolars (Bailey 2002), an asymmetric lingual contour, strong transverse crests and accessory lingual cusps are present (e.g., SD-763). The posterior dentition shows some cases of a noticeable taurodontism (e.g., SD-531). The mandibular body tends to be high and thick, and Neanderthal lineage features include mental foramen below M1, deep pterygoid fossa, and inclined mylohyoid line (Fig. 6).

On the other hand, the anatomy of cranial remains corresponds to the set of features detected in Late Pleistocene Neanderthals. The SD-436 frontal shows a marked anterior projection with the development of a supraglabellar fossa, and the supratoral sulcus is well defined; the degree of pneumatization is elevated. The temporal bones (SD-315 and SD-359) are still covered by concretions, but several diagnostic features can be distinguished, including a low projection of the mastoid process, flattened glenoid fossa, and an inclined anterior wall of this fossa. The 
occipital SD-1219 is large, with a marked nuchal torus and open sutures connecting with a wellpreserved temporal pyramid. A large suprainiac fossa is present. SD-1149 is smaller and partially covered by thin breccia. Right transverse sinuses are observed in both cases (Rosas et al. 2008).

The postcranial skeleton shows clear apomorphic features, in spite of its degree of fragmentation. The postcranial skeleton is principally represented by hand and foot metapodials and phalanges, the latter being the most abundant bones in the assemblage. Size and robustness of the first metacarpal and the enlarged distal tuberosity in the distal hand phalanges are among the diagnostic features (as defined by Musgrave 1973). Also, some Neanderthal dentine and enamel volumetric studies have been carried out by means of high-resolution imaging techniques (microCT) (Olejniczak et al. 2008).

Mitochondrial DNA (mtDNA) sequences have been retrieved so far from two El Sidrón samples (Lalueza-Fox et al. 2005, 2006): a right I2 (SD-441) and a femur fragment (SD-1252). The first sample yielded a 48-bp sequence (between positions 16230 and 16278 of the mtDNA reference sequence), and the second yielded an almost complete mtDNA hypervariable region 1 (302-nt sequence, between positions 16076 and 16378). Subsequently, nuclear DNA was studied, in particular specific genes FOX P2, related to oral ability (Krause et al. 2007), and MC1R, responsible for skin and hair pigmentation (Lalueza-Fox et al. 2007). During fieldwork, a non-contamination protocol for bone extraction in situ was followed (Fortea et al. 2008). These results have made it possible for El Sidrón to be included in the 'Neanderthal Genome' project of the Max Planck Institute, Leipzig (Germany).

\section{The archaeological evidence}

A total of 415 lithic artefacts have been recovered, including 13 cores, 352 flakes, 20 blades, 14 bladelets and 50 tools (Bordes 1961; Boëda 1993, 1994) comprising side scrapers, denticulates, a hand axe, and several Levallois points, flakes and blades (Fig. 7). The raw material comes from the immediate cave environment, and it is mostly chert (84\%), and quartzite (16\%).

The lithic assemblage is largely flake based, with a few laminar products and some Levallois supports. Up until now, 67 artefacts have been refitted, 18 of them belong to the same core; reflecting knapping at the primary location of the assemblage. This industry matches well with the Middle Palaeolithic flake industries that began in Europe in the middle part of the Middle Plaeistocene, remaining until the lower half of the Upper Pleistocene (Santamaría et al., in press).

\section{DATING}

The dating process consisted of determining the terminus ante quem and post quem of the sedimentary unit containing human remains; obtaining the chronology of organic or inorganic material contextually related to the Neanderthal fossils in the same sedimentary unit; dating the fossils themselves. For these purposes, the methods below have been used:

- optically stimulated luminescence (OSL): analysis of sediments bracketing the layer containing the human remains;

- uranium-series disequilibrium dating on flowstones interbedded with the sediments containing the human remains;

- amino acid racemization (AAR) dating of land snails associated with the human remains;

- radiocarbon dating $\left({ }^{14} \mathrm{C}\right.$ AMS $)$ of charcoal associated samples;

- electron spin resonance (ESR) dating of a human tooth;

- AAR dating of human teeth;

- ${ }^{14} \mathrm{C}$ AMS dating of human bones and teeth. 

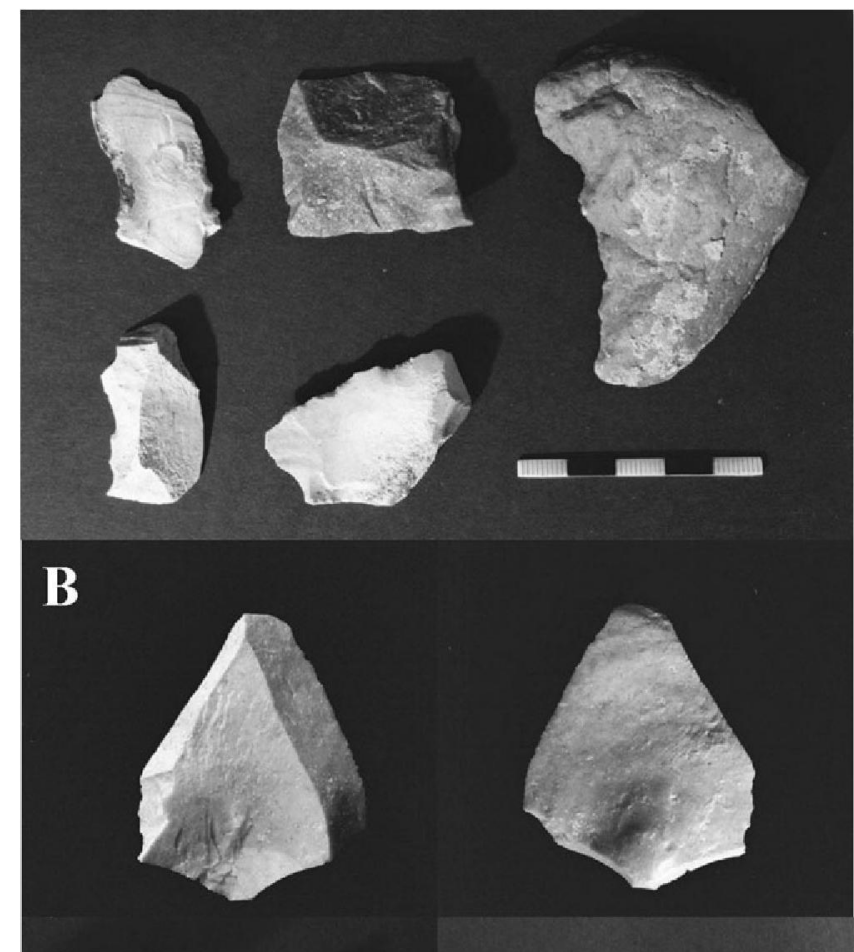

C
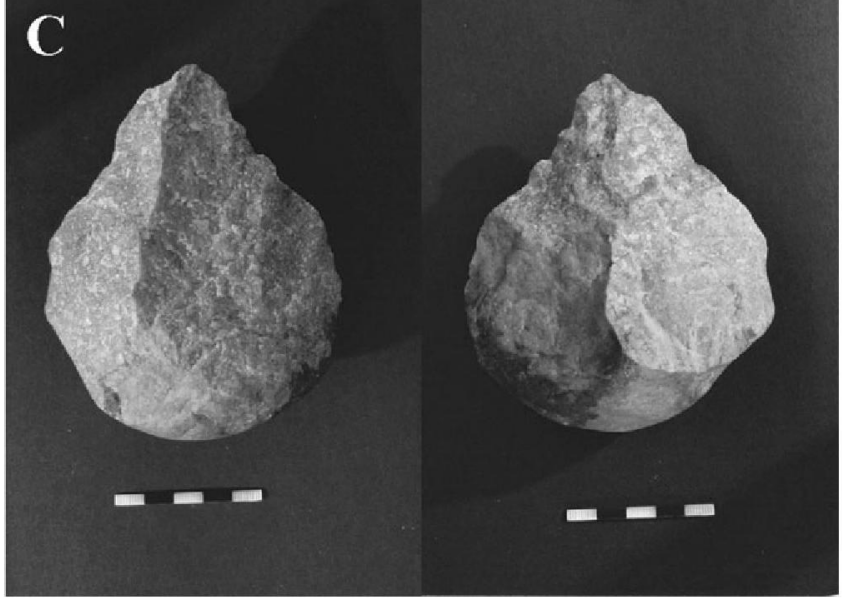

Figure 7 Lithic devices from El Sidrón cave (Photo J. Fortea).

For a more accurate and instructive analysis of the obtained age, it is interesting to establish a 'calendar of events'.

A bone sample was sent in 1996 to the University of Arizona but not enough collagen was found for ${ }^{14} \mathrm{C}$ AMS dating (SID-0/BS01, see Table 1). This negative result (due to bad collagen preservation or age of the sample) and the chronological amplitude of the Homo neanderthalensis suggested using other dating methods, without ruling out ${ }^{14} \mathrm{C}$. 


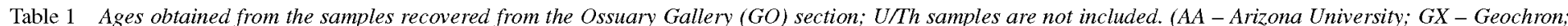
GIfA - Gif sur Yvette; Beta - Beta Analytic Laboratory; ANU - Australia National University; BSL - Biomolecular Stratigraphy Laboratory; OSL-Gif sur Yvette)

\begin{tabular}{|c|c|c|c|c|c|}
\hline Sample number & Invent. No. & Lab. ref. & Dating method & Type & Age BP \\
\hline SID-0/BSO1 & IAF & AA20283 & ${ }^{14} \mathrm{C}$ AMS & Hominid bone & Insuf. collagen \\
\hline SID-00A & $B / G$ & GifA99167 & ${ }^{14} \mathrm{C}$ AMS & Hominid bone & $48500 \pm 2600$ \\
\hline SID-00B & $\mathrm{B} / \mathrm{G}$ & GifA99704 & ${ }^{14} \mathrm{C}$ AMS & Hominid bone & $49200 \pm 2500$ \\
\hline SID-2A & 441 & GX-30241 & ${ }^{14} \mathrm{C}$ AMS & Hominid bone & $11289 \pm 79$ \\
\hline SID-3A & 531 & GX-30242 & ${ }^{14} \mathrm{C}$ AMS & Hominid molar & $10340 \pm 70$ \\
\hline SID-8B & 312 & Beta- 89644 & ${ }^{14} \mathrm{C}$ AMS & Hominid tooth & $34940 \pm 680$ \\
\hline SID-13 & 566 & Beta-189645 & ${ }^{14} \mathrm{C}$ AMS & Hominid tooth & Insuf. collagen \\
\hline SID-14 & 736 & Beta-189646 & ${ }^{14} \mathrm{C}$ AMS & Hominid bone & Insuf. collagen \\
\hline SID- 15 & 756 & Beta-189647 & ${ }^{14} \mathrm{C}$ AMS & Hominid tooth & Insuf. collagen \\
\hline SID-16 & 775 & Beta-189648 & ${ }^{14} \mathrm{C}$ AMS & Hominid tooth & Insuf. collagen \\
\hline SID- 17 & 748 & Beta-189649 & ${ }^{14} \mathrm{C}$ AMS & Hominid bone & Insuf. collagen \\
\hline SID- 18 & 50 & Beta-192064 & ${ }^{14} \mathrm{C}$ AMS & Hominid tooth & Insuf. collagen \\
\hline SID- 19 & 500 & Beta-192065 & ${ }^{14} \mathrm{C}$ AMS & Hominid tooth & $40840 \pm 1200$ \\
\hline SID-20 & $599 a$ & Beta-192066 & ${ }^{14} \mathrm{C}$ AMS & Hominid bone & $37300 \pm 830$ \\
\hline SID-21 & $763 a$ & Beta-192067 & ${ }^{14} \mathrm{C}$ AMS & Hominid tooth & $38240 \pm 890$ \\
\hline SID-1 & 9 & GX-28272 & ${ }^{14} \mathrm{C}$ AMS & Quercus. charcoal & $6070 \pm 40$ \\
\hline SID-4 & 3 & GX-30243 & ${ }^{14} \mathrm{C}$ AMS & Quercus. charcoal & $2230 \pm 50$ \\
\hline SID-5 & 7 & GX-30244 & ${ }^{14} \mathrm{C}$ AMS & Quercus. charcoal & $5990 \pm 60$ \\
\hline SID-6 & 12 & GX-30245 & ${ }^{14} \mathrm{C}$ AMS & Quercus. charcoal & $6200 \pm 60$ \\
\hline SID-2C & 441 & ANU & ESR & Hominid tooth & $\begin{array}{l}\text { EU: } 37000 \pm 3000 \\
\text { LU: } 40000 \pm 3000\end{array}$ \\
\hline SID-2B, 3B, 8A, 9 & $441,531,312,313$ & BSL-4069, 4374, 4068, 4063 & AARD & Hominid teeth & $\begin{array}{l}44400 \pm 8500 \\
\text { (average) }\end{array}$ \\
\hline SID-7 & 311 & BSL-4068 & AARD & Hominid tooth & Insuf. collagen \\
\hline SID- $10,11,12$ & & BSL-4179, 4180, 4181 & AARD & $\begin{array}{l}\text { Gastropod } \\
\text { (Cepaea nemoralis) }\end{array}$ & $\begin{array}{l}39400 \pm 7100 \\
\text { (average) }\end{array}$ \\
\hline SID-22 & & OSL-1 & OSL & Sediment & $46900 \pm 5200$ \\
\hline SID-23 & & OSL-5 & OSL & Sediment & $30400 \pm 2700$ \\
\hline SID-24 & & OSL-7 & OSL & Sediment & $28000 \pm 2500$ \\
\hline
\end{tabular}


After the commencement of the systematic excavations in 2000 by two of the authors (J.F. and M.R.), a new attempt was made to date the human remains. In 2001, five human teeth (SID-2B, SID-3B, SID-7, SID-8A and SID-9) were dated using the AAR method (AARD) at the Biomolecular Stratigraphy Laboratory of the Madrid School of Mines. The mean age, calculated using a four-point calibrated model, was reasonably old (Fortea et al. 2003), around $32 \pm 11 \mathrm{ka}$. Likewise, three land snail (SID-10, SID-11, SID-12) samples, which were recovered within the horizons containing the human remains, returned ages around $40 \mathrm{ka} \mathrm{BP}$.

In 2001 an enamel sample (SID-2C) was analysed using ESR in the Research School of Earth Sciences of the Australian National University (Canberra, Australia). The obtained age of about $40 \mathrm{ka}$ BP matched the data obtained through the amino acid racemization analysis.

Samples SID-2A, SID-2B and SID-2C (inventory number 441) were taken from the same specimen being ${ }^{14} \mathrm{C}, \mathrm{AARD}$ and ESR dated. Samples SID-3A and SID-3B (inventory number 531) also from the same specimen were ${ }^{14} \mathrm{C}$ and AARD dated (see Table 1).

In 2002 and 2003, a large set of flowstone samples was collected for Th/U dating. Some samples were picked from a flowstone interbedded in the human remain-bearing section. Other samples were taken for comparison from different flowstone deposits throughout the cave. Drip water was also sampled and analysed. All the samples were strongly contaminated with detrital thorium and almost all the ages obtained were out of the method range.

Human bone (SID-2A) and tooth (SID-3A) samples were sent to the Geochron Laboratories (Cambridge, MA) in 2003, and the results showed that the samples were astonishingly young, around $11 \mathrm{ka}$ BP 'in uncalibrated radiocarbon years'. Charcoal samples (SID-1, SID-4, SID-5, SID-6) gave younger dating (2-7 ka BP).

Taking into account the AAR and ESR ages obtained in 2003, a set of human bones and teeth (SID-8B, SID-13, SID-14, SID-15, SID-16, SID-17, SID-18, SID-19, SID-20, SID-21) was sent to Beta Analytic Laboratories (Florida, USA) in 2004. The results of around 35 and $40 \mathrm{ka}$ BP were consistent with those obtained earlier with AAR and ESR.

In 2005, a more complete calibration algorithm for dating dentine collagen was calculated at the Biomolecular Stratigraphy Laboratory based on new ${ }^{14} \mathrm{C}, \mathrm{U} / \mathrm{Th}$ and ESR dating results from many Iberian localities. The El Sidrón age was re-calculated and showed a better agreement with the aforementioned ages.

In 2006, OSL dating results on sediment samples (SID-22, SID-23 and SID-24) recovered in 2003 and 2005 from the GO section became available, again providing results consistent with the independent age estimates. In spite of many samples being signal-saturated due to the high radionuclide content of the sediments, the OSL age from the stratigraphical Unit II, underlying the bone-bearing Unit III, as well as the top of Unit III were consistently dated at 47 and $30 \mathrm{ka}$ $\mathrm{BP}$, respectively.

In 2006, the ${ }^{14} \mathrm{C}$ AMS results for the human femur sent by Vandermeersch and Garralda to the LSCE and dated in 1998 (unpublished, now included in this paper) became available. They yielded c. $49 \mathrm{ka} \mathrm{BP}$ (SID-00A and SID-00B in Table 1).

MATERIAL AND METHODS

\section{Radiocarbon dating}

The first set of samples (SID-2A, SID-3A, SID-1, SID-4, SID-5, SID-6) was sent to Geochron Laboratories. The charcoal fragments were separated for any foreign matter, including rootlets and treated with $1 \mathrm{~N} \mathrm{HCl}$ to remove carbonates, $\mathrm{NaOH}$ to remove humic acids and other organic 
contaminants, and followed by a further $\mathrm{HCl}$ treatment. Afterwards, the sample was combusted to recover $\mathrm{CO}_{2}$ for analysis. The human teeth samples were crushed and reacted with $1 \mathrm{~N} \mathrm{HCl}$ to dissolve the mineral fraction. The residue was filtered and washed and later boiled for $8 \mathrm{~h}$ in slightly acid distilled water. The broth was filtered through fibreglass. This process allowed the removal of rootlets, humic acids and other contaminants. The recovered collagen was combusted and the $\mathrm{CO}_{2}$ was recovered for analysis. All samples (charcoal and teeth) were dated using AMS. As complementary information, this laboratory only reported the $\delta^{13} \mathrm{C}$ value, which for the sample SID-2 was $-19.9 \%$ and for SID-3 was $-20.6 \%$ (Table 1).

Later, a wider set of bone and teeth samples was sent to Beta Analytic Laboratories (SID-8B, SID-13, SID-14, SID-15, SID-16, SID-17, SID-18, SID-19, SID-20, and SID-21). The samples were treated with alkali $(\mathrm{NaOH})$ to remove humic acids. Later, diluted $\mathrm{HCl}$ was applied until apatite was dissolved. For ${ }^{14} \mathrm{C}$ AMS analysis, the carbon sample was transformed into graphite, together with standards and blanks, and sent to an AMS facility. Some teeth sent to Beta Analytical were selected according to their collagen content, which was estimated according to their aspartic acid abundance during AAR analysis. From a total of 10 samples (human bone and teeth), only four had enough collagen for ${ }^{14} \mathrm{C}$ AMS dating (Table 1). As complementary information, this laboratory only reported the ${ }^{13} \mathrm{C}^{12} \mathrm{C}$ ratio, which for SID-19, SID-20 and SID-21 was $-18.1 \%$, $-18.1 \%$ and $-18.4 \%$, respectively.

Two samples (SID-00A and SID-00B) from the same human diaphysis fragment were dated at the LSCE. Elemental analysis $(\% \mathrm{C}, \% \mathrm{~N}, \mathrm{C} / \mathrm{N})$ performed on two subsamples yielded nitrogen and carbon content of 0.69 and $0.47 \%$ (for $\mathrm{N}$ ) and 2.95 and $1.78 \%$ (for $\mathrm{C}$ ), respectively, with $\mathrm{C} / \mathrm{N}$ ratios of 4.25 and 3.77 which suggest a rather good state of preservation of bone collagen.

The sample preparation was based on the specific reaction between collagen amino acids and ninhydrin (Nelson 1991). Each dating required c. $2 \mathrm{~g}$ of cortical bone which was crushed after being sandblasted with carbon-free alumina. After pretreatment with $0.5 \mathrm{~N} \mathrm{HCl}$ to remove the mineral fraction, the carbonate-free sample was treated with ninhydrin to eliminate any 'free' amino acids introduced from the archaeological sediment. After the collagen had been hydrolysed with $6 \mathrm{~N} \mathrm{HCl}$, a second treatment with ninhydrin allowed the extraction of $\mathrm{CO}_{2}$ from the carboxylic groups of amino acids (Tisnérat-Laborde et al. 2003). The extracted $\mathrm{CO}_{2}$ was reduced to graphite (Arnold et al. 1987), which was submitted to the 'Tandetron' AMS Facility (UMS2004) (Table 1). Bone 'blank' specimens were prepared and measured alongside the archaeological samples. The ${ }^{13} \mathrm{C}^{12} \mathrm{C}$ ratios measured during the AMS dating fall in the range of values obtained for bone; no other measurements were done on the mass spectrometer.

\section{Electron spin resonance dating}

ESR (and U-analysis) was carried out on an isolated incisor (SID-2C, Table 1). Because of the value of human material, we decided to follow semi-non-destructive analytical procedures (Grün 1995, 2006; Grün et al. 2003). A small piece of tooth enamel was removed along pre-existing breaks. During this process, the enamel separated completely from the dentine and was not further cleaned.

The enamel fragment was mounted in a Bruker ER 218PG1 programmable goniometer and measured at each dose step at $10^{\circ}$ angle intervals for $420^{\circ}$ (the spectra past $360^{\circ}$ were used to check for short-term fading effects). ESR measurements were carried out on a Bruker 106 spectrometer with a $15 \mathrm{kG}$ magnet and a rectangular 4102 ST cavity. The samples were recorded with the measurement parameters routinely applied in the laboratory of the Canberra Research School of Earth Sciences: accumulation of between 1200 (natural sample) and 200 scans (for the 


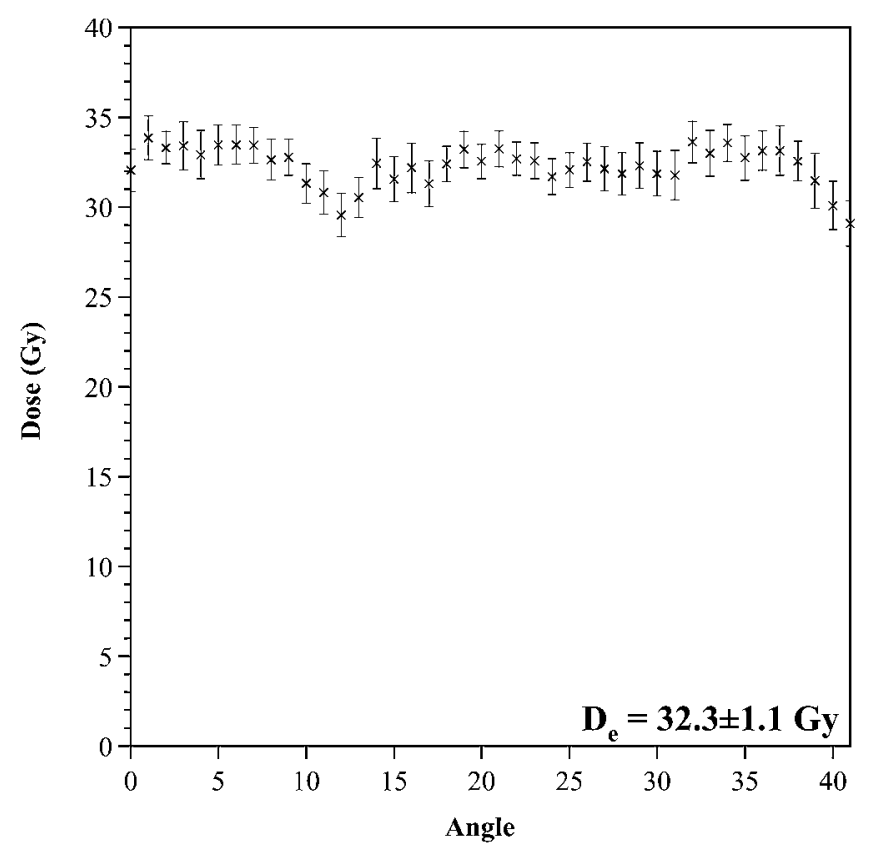

Figure 8 Dose plot for the Sidrón enamel sample.

higher dosed samples) with $1.015 \mathrm{Gpp}$ modulation amplitude, $10.24 \mathrm{~ms}$ conversion factor, $20.48 \mathrm{~ms}$ time constant, 2048 bit spectrum resolution (resulting in a total sweep time of $20.972 \mathrm{~s}$ ), $120 \mathrm{G}$ sweep width and $2 \mathrm{~mW}$ microwave power. The enamel piece was successively irradiated with the following cumulative doses: 0, 11.9, 23.5, 45.2, 68.4, 113, 152 and $197 \mathrm{~Gy}$. The total machine measuring time was 37 days. ESR intensity values were obtained by natural spectrum fitting (Grün 2002), dose values were obtained by applying a single saturating function with linear conversion, and errors were obtained by Monte Carlo simulation (Grün and Brumby 1994). Figure 8 shows the angular dose measurements, which yielded an average value of $32.3 \pm 1.1 \mathrm{~Gy}$.

The beta dose rate was determined from large sediment samples from Unit III in which the tooth was found. The sediment samples were collected in watertight plastic bags and analysed. The neutron activation results were $3.0 \pm 0.2 \mathrm{ppm} \mathrm{U}, 11.5 \pm 0.2 \mathrm{ppm}$ Th and $1.00 \pm 0.08 \% \mathrm{~K}$. The water content was assessed to be $23 \%$. The gamma dose rate was measured in situ with a Digidart portable CsI gamma spectrometer on both sides on the trench where Unit III was exposed, resulting in two measurements of $501 \pm 25$ and $540 \pm 27 \mu \mathrm{Gy} / \mathrm{a}$. Because of the discrepancy between the gamma spectrometric measurements and the NAA results (the latter would result in a dose rate of about $850 \mu \mathrm{Gy} / \mathrm{a}$ ), the isotopes of the U-decay chain were analysed with a high-resolution Ge detector system (Simpson and Grün 1998). The following isotope ratios were measured: ${ }^{230} \mathrm{Th} /{ }^{238} \mathrm{U}=1.06 \pm 0.08,{ }^{226} \mathrm{Ra} /{ }^{238} \mathrm{U}=1.06 \pm 0.03,{ }^{214} \mathrm{Bi} /{ }^{238} \mathrm{U}=1.01 \pm 0.01,{ }^{214} \mathrm{~Pb} /$ ${ }^{238} \mathrm{U}=1.00 \pm 0.01$ and ${ }^{210} \mathrm{~Pb} /{ }^{238} \mathrm{U}=0.99 \pm 0.02$. This means that the $\mathrm{U}$-decay chain is in equilibrium and that the discrepancy between the NAA and in-situ measurements is more likely caused by the fine sedimentary layering.

Uranium in the enamel and dentine was determined with laser ablation (for more details, see Eggins et al. 2003, 2005). The enamel was scanned twice, both scans resulting in closely similar $U$ distributions (Fig. 9). We obtained $U$ concentrations of $0.36 \pm 0.05$ (enamel) and 


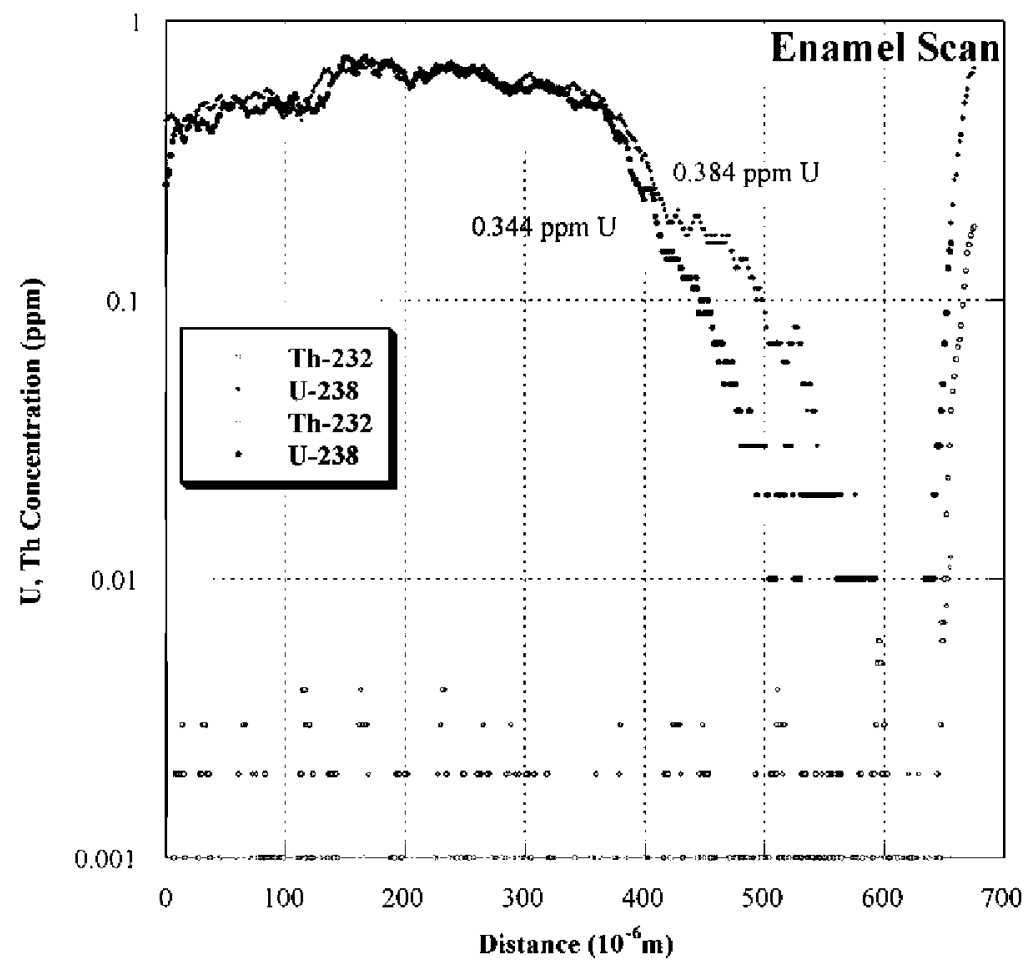

Figure 9 Laser ablation scans on the cross-section of an enamel sample.

$5.82 \pm 0.31 \mathrm{ppm}$ (dentine) and assumed a ${ }^{234} \mathrm{U} /{ }^{238} \mathrm{U}$ ratio of $1.2 \pm 0.2$ in enamel and dentine as well as $15 \pm 7 \%$ water in dentine.

\section{U-series disequilibrium dating of flowstones}

U-series dating of stalagmitic flowstones has been successfully used to establish the chronological framework of many archaeological sites in the Iberian Peninsula, such as Abric Romaní (Bischoff et al. 1994), El Castillo (Rink et al. 1997), L’Arbreda (Bischoff et al. 1994), Banyoles (Julià and Bischoff 1991) and Atapuerca (Bischoff et al. 1997, 2003).

Twenty-two samples were recovered in El Sidrón cave for U/Th dating purposes (Table 2). Twenty-one samples were recovered from calcitic flowstones and one sample consisted of dripping water. The isotopic composition of the samples was determined by alpha spectroscopy.

Ten samples were taken on a single calcarenitic bed correlated with the horizon where the Neanderthal remains appear in the GO section. Eleven samples were recovered from speleothem throughout the cave, with uncertain relation with the Neanderthal remains and underlying -overlying sediments attesting the complex infill history of the cave.

For the principles of the U-series dating technique, the reader is referred to Ivanovich and Harmon (1992). Chemical separation followed Bischoff and Fitzpatrick (1991): the sample was totally dissolved in nitric acid and a radioisotope with known activity was incorporated in order to determine the efficiency of the isotope separation process. The $U$ and Th isotopes were isolated 


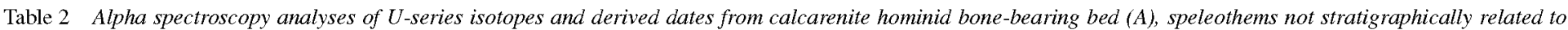
the Neanderthal remains bearing section $(B)$ and dripping water $(C)$

\begin{tabular}{|c|c|c|c|c|c|c|c|c|c|}
\hline & Ref. & $U p p m$ & Th ppm & ${ }^{234} U{ }^{238} U$ & ${ }^{230} T h^{234} U$ & ${ }^{230} T h{ }^{232} T h$ & ${ }^{234} U^{232} T h$ & ${ }^{238} U^{232} T h$ & Nominal date \\
\hline \multirow[t]{10}{*}{$\mathbf{A}$} & $603-\mathrm{T}$ & 0,2 & 0,42 & $1.12 \pm 0.02$ & $0.46 \pm 0.01$ & $0.766 \pm 0.022$ & $1.652 \pm 0.049$ & $1.474 \pm 0.045$ & $66746+2916 /-2843$ \\
\hline & $1104-\mathrm{L}$ & 0,15 & 1,56 & $1.02 \pm 0.03$ & $2.89 \pm 0.08$ & $0.860 \pm 0.010$ & $0.298 \pm 0.008$ & $0.292 \pm 0.008$ & $*$ \\
\hline & 1604-R & 1,45 & 7,62 & $0.95 \pm 0.06$ & $1.07 \pm 0.06$ & $0.598 \pm 0.021$ & $0.561 \pm 0.029$ & $0.590 \pm 0.030$ & * \\
\hline & $1204-\mathrm{T}$ & 0,34 & 1,88 & $0.90 \pm 0.05$ & $1.51 \pm 0.13$ & $0.756 \pm 0.030$ & $0.500 \pm 0.041$ & $0.554 \pm 0.045$ & $*$ \\
\hline & $61012-\mathrm{T}$ & 0,14 & 0,85 & $0.96 \pm 0.02$ & $1.57 \pm 0.03$ & $0.772 \pm 0.008$ & $0.491 \pm 0.010$ & $0.512 \pm 0.010$ & $*$ \\
\hline & 1304-L & 0,16 & 1,00 & $1.04 \pm 0.02$ & $1.75 \pm 0.10$ & $0.882 \pm 0.045$ & $0.504 \pm 0.029$ & $0.485 \pm 0.028$ & $*$ \\
\hline & 1704-R & 3,97 & 21,22 & $1.01 \pm 0.04$ & $0.96 \pm 0.04$ & $0.565 \pm 0.015$ & $0.589 \pm 0.024$ & $0.581 \pm 0.023$ & $*$ \\
\hline & $1404-\mathrm{L}$ & 0,33 & 3,68 & $1.01 \pm 0.03$ & $2.43 \pm 0.08$ & $0.688 \pm 0.008$ & $0.283 \pm 0.009$ & $0.280 \pm 0.009$ & $*$ \\
\hline & $1504-\mathrm{L}$ & 0,24 & 2,24 & $1.04 \pm 0.04$ & $2.41 \pm 0.12$ & $0.821 \pm 0.023$ & $0.341 \pm 0.016$ & $0.328 \pm 0.016$ & $*$ \\
\hline & 2204-R & 1,6 & 8,15 & $1.08 \pm 0.07$ & $0.97 \pm 0.06$ & $0.639 \pm 0.025$ & $0.658 \pm 0.039$ & $0.609 \pm 0.037$ & * \\
\hline \multirow[t]{11}{*}{ B } & $6201-\mathrm{T}$ & 0,11 & 0,54 & $0.94 \pm 0.02$ & $0.94 \pm 0.03$ & $0.54 \pm 0.011$ & $0.573 \pm 0.016$ & $0.607 \pm 0.016$ & $*$ \\
\hline & $6301-\mathrm{T}$ & 0,09 & 0,46 & $1.01 \pm 0.04$ & $1.19 \pm 0.05$ & $0.684 \pm 0.017$ & $0.577 \pm 0.022$ & $0.573 \pm 0.022$ & $*$ \\
\hline & $6401-\mathrm{T}$ & 0,15 & 0,83 & $0.97 \pm 0.03$ & $1.08 \pm 0.04$ & $0.589 \pm 0.011$ & $0.546 \pm 0.017$ & $0.564 \pm 0.017$ & $*$ \\
\hline & $303-\mathrm{T}$ & 0,42 & 1,66 & $1 \pm 0.02$ & $0.83 \pm 0.07$ & $0.645 \pm 0.04$ & $0.774 \pm 0.062$ & $0.777 \pm 0.063$ & $194899+62245 /-39270$ \\
\hline & $403-\mathrm{T}$ & 0,55 & 2,35 & $1.02 \pm 0.02$ & $0.75 \pm 0.02$ & $0.558 \pm 0.007$ & $0.741 \pm 0.019$ & $0.727 \pm 0.019$ & $150682+9010 /-8325$ \\
\hline & $503-\mathrm{L}$ & 0,14 & 0,51 & $1.11 \pm 0.04$ & $0.84 \pm 0.03$ & $0.789 \pm 0.017$ & $0.943 \pm 0.033$ & $0.851 \pm 0.030$ & $185143+17958 /-15507$ \\
\hline & $703-\mathrm{R}$ & 3,19 & 8,80 & $0.91 \pm 0.02$ & $0.71 \pm 0.04$ & $0.726 \pm 0.038$ & $1.027 \pm 0.053$ & $1.125 \pm 0.058$ & $137647+17335 / 14850$ \\
\hline & $3002-\mathrm{T}$ & 0,09 & 0,61 & $0.99 \pm 0.04$ & $2.38 \pm 0.09$ & $1.073 \pm 0.021$ & $0.450 \pm 0.016$ & $0.455 \pm 0.016$ & $*$ \\
\hline & $3102-\mathrm{T}$ & 0,18 & 0,77 & $0.98 \pm 0.03$ & $0.98 \pm 0.04$ & $0.691 \pm 0.017$ & $0.709 \pm 0.027$ & $0.720 \pm 0.027$ & * \\
\hline & $203-\mathrm{T}$ & 0,14 & 0,71 & $0.97 \pm 0.04$ & $1.03 \pm 0.08$ & $0.617 \pm 0.043$ & $0.597 \pm 0.041$ & $0.619 \pm 0.043$ & $*$ \\
\hline & $3202-\mathrm{T}$ & 3,97 & 12,41 & $0.99 \pm 0.01$ & $0.45 \pm 0.03$ & $0.445 \pm 0.010$ & $0.987 \pm 0.056$ & $0.993 \pm 0.056$ & $65086+5305 /-5010$ \\
\hline C & 3302 & $1,7610^{-3}$ & $1.2210^{-3}$ & $1.22 \pm 0.07$ & $0.26 \pm 0.02$ & $1.428 \pm 0.115$ & $5.473 \pm 0.407$ & $4.495 \pm 0.344$ & $32508+2515 /-2462$ \\
\hline
\end{tabular}

$\mathrm{T}=$ total sample dissolution, $\mathrm{L}=\mathrm{HNO}_{3}$, leachable fraction, $\mathrm{R}=\mathrm{HNO}_{3}$, insoluble fraction.

* No date could be obtained due to detrital Th contamination. 
by ion-exchange chromatography and later analysed in an alpha spectrometer. For age calculation, the UDATE program from Rosenbauer (1991) was used.

The method's reliability depends on the chemical purity of the samples. Only six samples provided nominal dates younger than the method limit of about $350 \mathrm{ka}$ (Table 2).

\section{Optically stimulated luminescence dating}

Nine sediment samples were collected by hammer-driven $20 \mathrm{~cm}$ long aluminium tubes in the sections. The exposed surface had been scraped to avoid contamination by grains bleached during the excavation. The current gamma dose rates were measured in situ by inserting a Nanoprobe portable spectrometer equipped with a 1.5 inch Na detector into the sampling holes. The recorded dose rates ranged from 562 to $856 \mu \mathrm{Gy} / \mathrm{a}$; the lower dose value is similar to the in-situ dose value obtained by Gruin (this paper) using a different portable gamma spectrometer (501-540 $\mu \mathrm{Gy} / \mathrm{a}$ ). The observed variation in the dose rates (a factor 1.5) may be due to mineralogical heterogeneity in the sampled beds.

The samples were treated to extract middle-sized quartz grains $(80-100 \mu \mathrm{m})$ by sieving and acid leaching (hydrochloric, hydrofluoric and hexafluorosilicic acids) to dissolve carbonate and feldspar grains. Hydrogen peroxide was used to eliminate organics.

A large number of aliquots were prepared from each sample, placing small amounts of quartz grains on stainless-steel discs; silicon oil was used as an adhesive. It can be estimated that each aliquot contained about 100 grains. The luminescence measurements were performed using a TL/OSL-DA-15 Ris $\emptyset$ reader equipped with a ${ }^{90} \mathrm{Sr} /{ }^{90} \mathrm{Y}$ beta source. Optical stimulation was by blue light-emitting diodes (LEDs) with peak emission at $470 \mathrm{~nm}$ (Bøtter-Jensen et al. 2000). OSL signals were detected with an EMI 9235QA photomultiplier tube through three $3 \mathrm{~mm}$ Hoya U-340 filters.

The determination of the ED value of each aliquot followed the single-aliquot regenerative (SAR) dose protocol (Murray and Wintle 2000). The method allows the construction of a sensitivity-corrected regenerative OSL dose-response curve. The ED can then be calculated via interpolation of the corrected natural OSL signal on a saturating exponential curve fitted towards the corrected regenerative dose signals (Fig. 10). A first series of measurements was carried out for the determination of the temperature to which the aliquots have to be preheated for removing unstable signals prior to the luminescence measurements (Fig. 11). This temperature was $250^{\circ} \mathrm{C}$ for $10 \mathrm{~s}$. Afterwards the SAR protocol was validated on six of the nine samples by performing recovery dose tests. In this second set of experiments, quartz grains were bleached with the LEDs and the aliquots irradiated with the beta dose of $60 \mathrm{~Gy}$. For each sample, the SAR protocol was applied to eight aliquots. The mean measured doses ranged from $59.4 \pm 2.4$ to $60.6 \pm 3.0 \mathrm{~Gy}$, thus validating the measurement conditions.

\section{Amino acid racemization method}

Three gastropod shells (Cepaea nemoralis Linnaeus) as well as five Homo neanderthalensis teeth (three incisors, one premolar and one molar) were analysed (Table 1). The gastropod remains came from the same stratigraphical unit where the Homo neanderthalensis remains were found. The gastropod shells were sonicated and cleaned with water to remove sediment. Peripheral parts, approximately $20-30 \%$, were eliminated after chemical cleaning of the sample with $2 \mathrm{~N} \mathrm{HCl}$. The weight of material used for amino acid racemization analysis was $70-90 \mathrm{mg}$. 


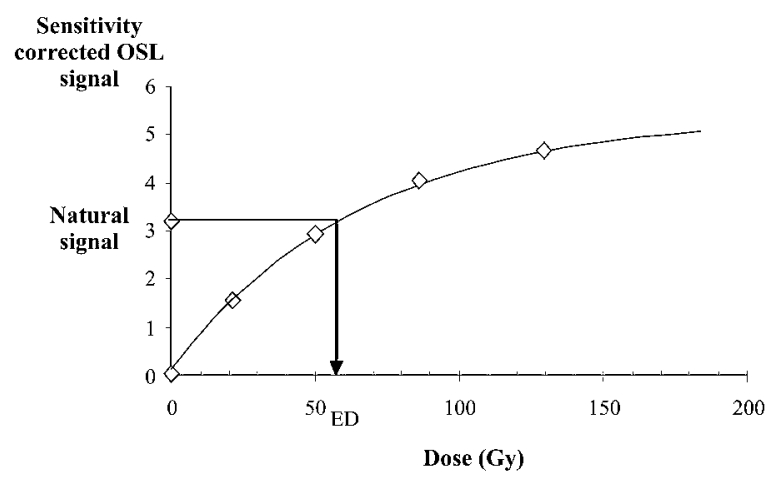

Figure 10 Sensitivity-corrected regenerative OSL dose-response curve of an aliquot of sample OSL-1. The sensitivity changes which may affect the quartz are corrected in measuring after each regenerative dose (here 20,50,87, 132, 0 and $20 \mathrm{~Gy}$ ); the OSL signal is induced by a constant dose (a test dose preheated at $160^{\circ} \mathrm{C}$ ). The efficiency of this correction is evaluated by measuring the signals induced by a same dose - here $20 \mathrm{~Gy}$-given at the beginning and end of the measurement cycle. The ED was calculated by interpolation of the corrected natural OSL signal onto a saturating exponential curve fitted towards the corrected regenerative dose signals.

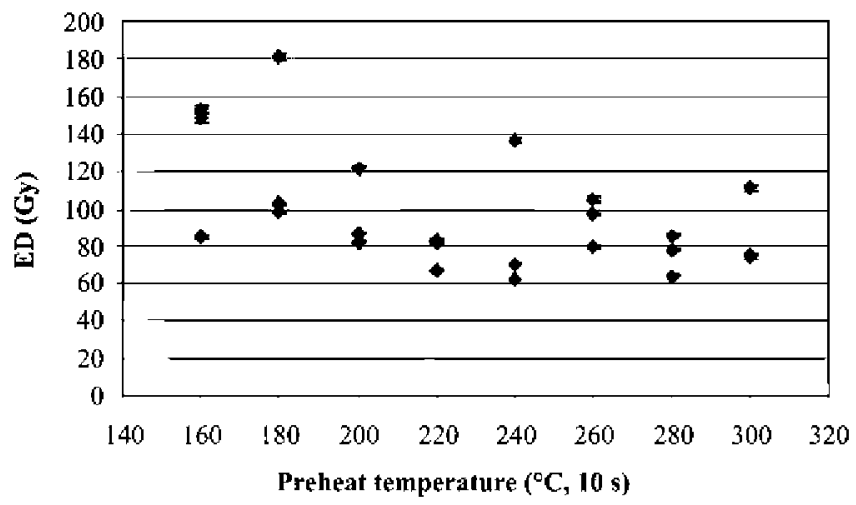

Figure 11 EDs of 24 aliquots of sample OSL-1 measured with different preheat temperatures (from 160 to $300^{\circ} \mathrm{C}$ in steps of $20^{\circ}$. This test allows us to choose a preheat temperature of $250^{\circ} \mathrm{C}$ for $10 \mathrm{~s}$ which was systematically applied to the regenerative doses in all the following measurements.

The Biomolecular Stratigraphy Laboratory (BSL) uses dentine for amino acid racemization dating of vertebrates. The use of bones is rejected because they are more prone to diagenetic interference (Masters 1986). Dentine collagen samples were obtained by drilling the root of the teeth with a dental diamond drill. A hole $2-3 \mathrm{~mm}$ in diameter was drilled near the tooth neck, trying to reach the part of the dentine, which is most protected by the crown. Between 5.5 and $16 \mathrm{mg}$ of dentine were obtained. The outermost part of the root (mostly cementum) was rejected. The samples were pretreated to eliminate foreign and indigenous free amino acids (Marzin 1990; Torres et al. 1999, 2000) through a first acid $(\mathrm{HCl})$ treatment at room temperature and a posterior dialysis step (Spectra/Por mnco $3500 \mathrm{D}$ membrane) to eliminate dissolved mineral fraction and free amino acids. The sample preparation and analysis protocols are described in Goodfriend (1991) and Goodfriend and Meyer (1991) for mollusc-derived proteins. 


\section{RESULTS AND DISCUSSION}

\section{Radiocarbon dating}

The ${ }^{14} \mathrm{C}$ ages obtained at the Beta Analytic Laboratory (four dates) and the two obtained at the LSCE range from $c$. 35000 to 49000 years BP; the results obtained in each laboratory are internally coherent. However, the Beta Analytic Laboratory ages are younger than those of the LSCE. Such a wide age range can be explained by assuming that the site saw several occupation periods between 35000 and 50000 years BP, but the sedimentary infill and the bone and lithic refittings are at odds with this explanation. Another possibility is that the site was only occupied during part of this period, but some of the ${ }^{14} \mathrm{C}$ ages are possibly underestimated due to contamination by modern carbon.

One has to keep in mind that for the time period in question even a small amount of contamination by modern carbon has an important impact on the results. For instance, the presence of only $0.5 \%$ of modern carbon in a 50000 -year-old sample results in an age underestimate of c. 9000 years (Delibrias 1985; Bronk-Ramsey et al. 2004). Compared to the Beta Analytic Laboratory protocol which uses the whole collagen for the dating, the ninhydrin protocol is more selective as it allows extraction of the $\mathrm{CO}_{2}$ from the carboxylic groups of amino acids. This protocol is more effective in eliminating carbonaceous contamination and isolating the intrinsic carbon of the bone. Hence, the oldest ages are probably more reliable so that the Sidrón human remains can be considered to be older than 45000 years BP.

In contrast, the two $c .11000$ years ${ }^{14} \mathrm{C}$ yr BP dates (SID-2A, SID-3A) obtained at the Geochron Lab. on the hominid bone (SID-2A) and molar (SID-3A) are much younger than the ESR and AARD results (between 37000 and 44000 years) obtained on the same samples (Table 1). It is also obvious that the dated Quercus charcoals (SID-1, SID-4, SID-5 and SID-6) between 2000 and 6000 years are much younger than the Palaeolithic occupation. Consequently one cannot exclude the possibility that the samples dated at the Geochron Lab. were severely contaminated by modern carbon and that the radiocarbon ages are underestimated. One can also suggest that the Quercus trees grew during the Holocene period and that they were introduced late into the Palaeolithic layer.

\section{ESR and U-analysis}

For age calculation, we used an updated version of the ESR-DATA program which uses the Monte Carlo beta attenuation values of Marsh (1999) and an alpha efficiency of $0.13 \pm 0.02$ (Grün and Katzenberger-Apel 1994). The resulting ESR age estimates are $37 \pm 3 \mathrm{ka}$ for early uranium uptake and $40 \pm 3 \mathrm{ka}$ for linear U-uptake (for more details on U-migration and modelling, see Grün and McDermott 1994). At present, we are not able to further constrain the U-uptake history, therefore the best age estimate for the tooth lies between 34 and $43 \mathrm{ka}$.

\section{Uranium/thorium from flowstones}

The results of radiometric age calculation appear in Table 2. It is noticeable that there is a very high ${ }^{230} \mathrm{Th}$ contamination. In all samples the value of the ${ }^{230} \mathrm{Th} /{ }^{232} \mathrm{Th}$ ratio is above the threshold value (20) established by many authors (Schwarcz 1980; Ford and Schwarcz 1981; Julià and Bischoff 1991; Bischoff et al. 1994; Horvatincic et al. 2000; Auler and Smart 2001). This extremely high Th contamination, the dripping water has a nominal age older than $30 \mathrm{ka}$, makes 
OSL- 2

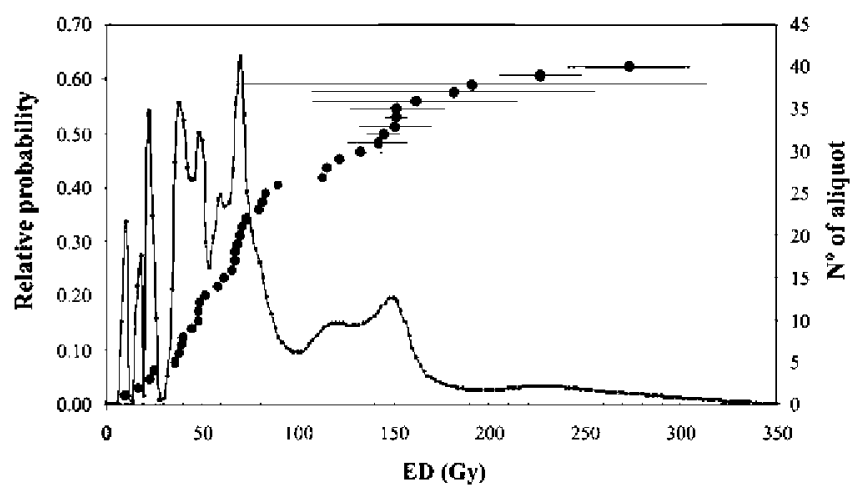

Figure 12 Histogram of EDs obtained on 40 aliquots. Each individual ED value is represented by a Gaussian curve, the area of which is normalized (left axis). The values are also displayed by rank order (right axis). Note the large spread of the values ranging from about 10 to $275 \mathrm{~Gy}$.

it unrealistic to try to use the isochron method proposed by Bischoff and Fitzpatrick (1991) and $\mathrm{Ku}$ and Liang (1984) to remove discrete ${ }^{232} \mathrm{Th}$ contamination. In any case, the radionuclide concentrations along the same bed were also extremely variable, confirming the unreliability of these methods for these materials.

The uranium-series disequilibrium method did not work adequately in El Sidrón cave sediment samples.

\section{Optically stimulated luminescence dating}

Because the OSL was saturated in most of the aliquots of six samples, it was not possible to calculate their EDs. This probably indicated that the quartz grains were scarcely exposed to sunlight in the open air environment before their transportation into the cave; in any case, any reworking process inside the ossuary gallery took place in total darkness. For the remaining aliquots, the scattering of the EDs was very large (see histogram of Fig. 12). Only three sediment samples (SID-22, SID-23 and SID-24) produced good results - see an example in Figure 13. For these three samples, the mean ED was estimated by considering the highest probability of each histogram, i.e., the highest peak was interpreted to be the main component of the sediment. The obtained values for samples SID-22, SID-23 and SID-24 were 53.5 $\pm 3.6,43.3 \pm 0.6$ and $51.0 \pm 0.8 \mathrm{~Gy}$, respectively (Table 3 ).

The OSL ages were $46.9 \pm 5.2 \mathrm{ka}, 30.4 \pm 2.7 \mathrm{ka}$ and $28.0 \pm 2.5 \mathrm{ka}$ for samples SID-22, SID-23 and SID-24 (Table 3). Samples SID-22 and SID-23 were located in archaeological layers IVB and top IIIA, respectively (sedimentary units I and top III; see above: Sedimentology and stratigraphy), thus bracketing the human-bearing beds. Sample SID-24 was recovered from a higher stratigraphical layer (Figs 3 and 5).

\section{Amino acid racemization}

The amino acid racemization/epimerization ratios obtained in the gastropod and dentine collagen samples are detailed in Tables 4 and 5. For the dentine collagen, the age calculation was made 
OSL- 1

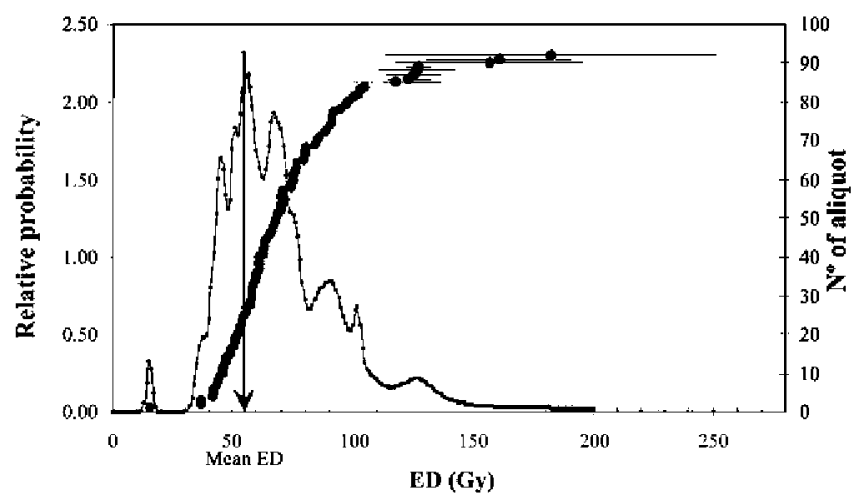

Figure 13 For this sample, a main peak is discemible on the histogram. The mean ED used for calculating the OSL age was estimated by fitting a normal distribution on the main peak.

Table 3 Radiometric data and OSL ages for samples SID-22, SID-23 and SID-24. The alpha, beta and gamma dose rates were calculated using the conversion factors of Adamiec and Aitken (1998)

\begin{tabular}{|c|c|c|c|c|c|c|c|c|c|}
\hline \multirow[t]{2}{*}{ Sample } & \multirow[t]{2}{*}{$U(p p m)$} & \multirow[t]{2}{*}{$T h(p p m)$} & \multirow[t]{2}{*}{$K(\%)$} & \multicolumn{4}{|c|}{ Dose rate $(\mu G y / a)$} & \multirow[t]{2}{*}{$E D(G y)$} & \multirow[t]{2}{*}{ Age (ka) } \\
\hline & & & & alpha & beta & gamma & total & & \\
\hline SID-22 & 1.77 & 6.3 & 0.56 & 36.5 & 604.9 & 499.3 & $1140.8 \pm 10.8$ & $53.5 \pm 3.6$ & $46.9 \pm 5.2$ \\
\hline SID-23 & 2.45 & 6.89 & 0.75 & 44.6 & 791.2 & 590.0 & $1425.9 \pm 51.3$ & $43.3 \pm 0.6$ & $30.4 \pm 2.7$ \\
\hline SID-24 & 3.08 & 10.5 & 0.73 & 61.9 & 902.1 & 856.0 & $1820.1 \pm 76.4$ & $51.0 \pm 0.8$ & $28.0 \pm 2.5$ \\
\hline
\end{tabular}

from aspartic acid (Asp) racemization ratios because of its higher racemization rate. The aspartic acid $\mathrm{D} / \mathrm{L}$ ratios of Homo neanderthalensis dentine collagen samples were introduced in the age calculation algorithm established for dentine collagen samples of bears (Ursus deningeri and Ursus spelaeus) from the Iberian Peninsula by Torres et al. (2001, 2002). The age calculation algorithms employed for Cepaea nemoralis samples are those established by Torres $e$ t al. (1997).

It is noteworthy that the D/L Asp values reported here differ from a single value $(0.13)$ published in Lalueza-Fox et al. (2005), which did not significantly differ from the "magic threshold' (0.10) for DNA preservation (Poinar et al. 1996). We think that this value was obtained from the total amino acid content, where the contribution of free amino acid fraction to the Asp racemization ratio may bias the final result due to its higher racemization rate (e.g., Ohtani and Yamamoto 1991).

For the age-calculation algorithm, we used the racemization values from eight cave localities dated through different radiometrical methods. In any case we have calculated the mean age from the individual values obtained from each sample and the age uncertainty is the standard deviation. The mean age for the dentine collagen samples from the Neanderthal teeth was $44.4 \pm 8.5 \mathrm{ka}$ BP (Fig. 14). 
Table 4 Amino acid racemization ratios obtained in Cepaea nemoralis shells from El Sidron cave. The abundance of each amino acid $(D+L$ forms) is also presented (peak areas are corrected for $100 \mathrm{mg}$ sample weight and $4 \mu$ injected volume)

\begin{tabular}{lccc}
\hline \hline & & & \\
Sample & $B S L-4179$ & $B S L-4180$ & $B S L-4181$ \\
\hline Weight (mg) & 80 & 91.5 & 67 \\
Alanine & 6871 & 9157 & 3613 \\
D/L Ala & 0.280 & 0.275 & 0.360 \\
Valine & 12428 & - & 5966 \\
D/L Val & 0.351 & - & 0.285 \\
Leucine & 1272 & 1650 & 729 \\
D/L Leu & - & - & - \\
Aspartic acid & 10285 & 14738 & 4876 \\
D/L Asp & 0.382 & 0.340 & 0.404 \\
Glutamic acid & 12008 & 16433 & 3023 \\
D/L Glu & 0.175 & 0.148 & 0.170 \\
Phenylalanine & 2844 & 3683 & 1275 \\
D/L Phe & 0.282 & 0.234 & 0.271 \\
Isoleucine & 3068 & 3794 & 1115 \\
D-alle/L-Ile & 0.183 & 0.153 & 0.158 \\
\hline \hline
\end{tabular}

Table 5 Aspartic acid ratios obtained in Homo neanderthalensis (Fuhlrott and Schaaffhausen) dentine collagen samples from El Sidrón cave. The abundance of the aspartic acid $(D+L$ forms) is also presented (peak areas are corrected for $100 \mathrm{mg}$ sample weight and $4 \mu \mathrm{l}$ injected volume). The results for other amino acids are not used for age calculation because D-forms were not detected in the analysis

\begin{tabular}{lccccc}
\hline \hline Sample & BSL-4063 & $B S L-4064$ & $B S L-4068$ & $B S L-4069$ & $B S L-4374$ \\
\hline Tooth & $\mathrm{I}^{1}$ & $\mathrm{P}^{4}$ & $\mathrm{I}^{1}$ & $\mathrm{I}^{2}$ & $\mathrm{M}$ \\
Weight (mg) & 12 & 16 & 8.5 & 5.5 & 14 \\
Aspartic acid & 1393917 & 27337438 & - & 89933455 & 463814 \\
D/L Asp & 0.062 & 0.084 & - & 0.057 & 0.067 \\
\hline \hline
\end{tabular}

In the case of gastropod samples we used the calculated ages from the racemization ratios of seven different amino acids but the final age was calculated as the mean value of the ages obtained from each amino acid from the three samples. For gastropods the average age was $39.4 \pm 7.1 \mathrm{ka}$ BP (Fig. 15).

\section{CONCLUSIONS}

Most of the dates based on radiometric methods applied to samples of different nature which come from the Palaeolithic levels (bones or teeth dated by C-14 BP uncalibrated, ESR and AARD) or on the geological context (quartz dated by OSL) fall between 38000 and 50000 years BP, showing that the Sidron human remains might be contemporaneous with the last millennia of the Middle Palaeolithic. Actually the most reliable C-14 results are those obtained at the LSCE because the bone preparation used in this laboratory is more effective in eliminating modern 


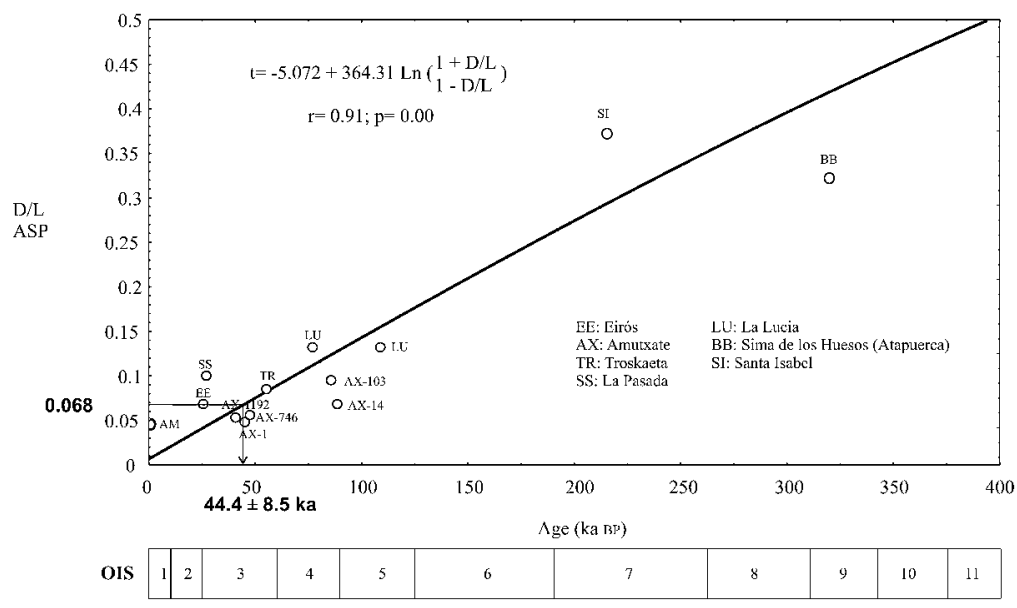

Figure 14 Age calculation of Homo neanderthalensis teeth from El Sidrón cave by introducing the aspartic acid D/L ratios of the dentine collagen into the dating algorithm established for dentine collagen aspartic acid $D / L$ ratios of bears (Ursus deningeri and Ursus spelaeus) from different Iberian localities (modified from Torres et al. 2001, 2002). Circles represent the bear localities dated by different dating methods: ${ }^{14} \mathrm{C}$ in bones (Eirós cave, Galicia; Grandal d'Anglade and Vidal Romani 1997), Th/U in speleothems (La Lucia cave, Cantabria; Torres et al. 2001), electron spin resonance (ESR) and uranium series in bear teeth (Sima de los Huesos, Burgos; Bischoff et al. 1997) and unpublished ESR data obtained from bear teeth (Amutxate cave, Navarra; Troskaeta and Santa Isabel caves, Vizcaya; La Lucia and La Pasada caves, Cantabria).

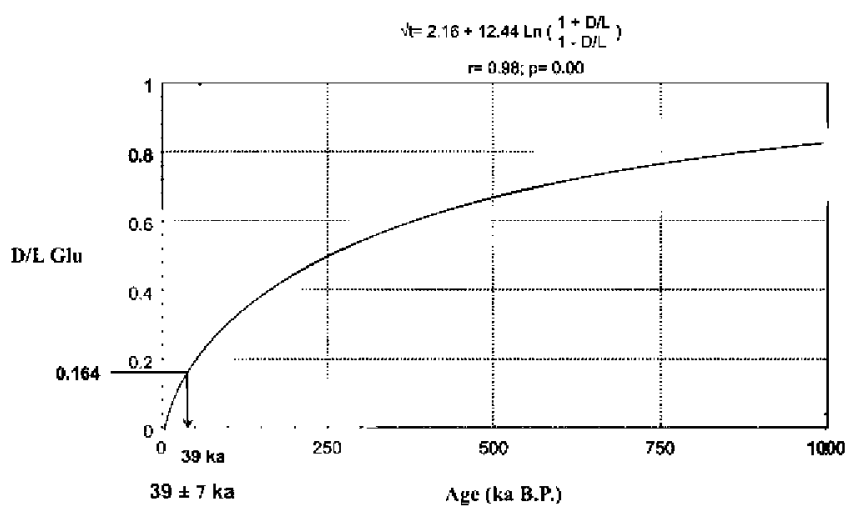

Figure 15 Age calculation of Cepaea nemoralis samples from El Sidrón cave using the glutamic acid D/L ratios. The dating algorithm appears in Torres et al. (1997).

carbon contamination present in the sample which would otherwise yield an age underestimate. The uncertainty ranges of the other methods used are large enough for the results to be compatible with the oldest radiocarbon dates. In any case, some fossil bone samples are to be dated soon with the ultrafiltration method (Brown et al. 1988; Higham et al. 2006), which has also proved to be adequate for dating old and contaminated bone remains.

On the right-hand side of Figure 5, there is a synthetic section of the GO stratigraphy with the different age values obtained by the different dating methods. This allows us to confidently date the Homo neanderthalensis remains from El Sidrón cave more than a few millennia before $40 \mathrm{ka}$, 
during the OIS 3, before Homo sapiens arrived in Europe. These results place the Sidrón archaeological record in the interval between the GIS 10 and 14, at the latest phase of the Middle Palaeolithic, as at some other Cantabrian sites, such as La Viña (Asturias, Spain), El Mirón, El Castillo (Cantabria, Spain), Arrillor, Axlor or Kurtzia (Basque Country, Spain) (Hoyos et al. 1999; Fortea 2001; Jöris et al. 2003; Straus and González Morales 2003; Bernaldo de Quirós and Stuart 2006).

\section{ACKNOWLEDGEMENTS}

This work was supported by Principado de Asturias-Universidad de Oviedo Grants CN-00-184D3; CN-01-132,133,134-B1; CN-04-152, Plan I+D+I Fycit-Principado de Asturias Grant FC02-Pc-SPV01-27 and Principado de Asturias 'Severo Ochoa Program' PCTI 2006/2009. Partial aspects of the research are included in Project BOS2003-01531, Spanish Ministerio de Educacion y Ciencia. We have to thank José Luis Seoane (University of Oviedo) for suggestions in some figures.

\section{REFERENCES}

Arnold, M., Bard, E., Maurice, P., and Duplessy, J. C., 1987, 14C dating with the Gif-sur-Ivette Tandetron accelerator: status report, Nuclear Instruments and Methods in Physics Research, B29, 120-3.

Auler, A. S., and Smart, P. L., 2001, Late quaternary paleoclimate in semiarid northeastern Brazil from U-series dating of travertine and water-table speleothems, Quatemary Research, $\mathbf{5 5}(2), 159-67$.

Bailey, S. E., 2002, A closer look at Neanderthal postcanine dental morphology: the mandibular dentition, The Anatomical Record (New Anat.), 269, 148-56.

Bermúdez de Castro, J. M., 1993, The Atapuerca dental remains. New evidence (1987-1991 excavations) and interpretations, Joumal of Human Evolution, 24(5), 339-71.

Bernaldo de Quirós, F. C., Cabrera, V., and Stuart, A. J., 2006, Nuevas dataciones para el musteriense y el magdaleniense de la cueva de El Castillo, in En el centenario de la cueva de El Castillo: El Ocaso de los Neandertales (eds. V. Cabrera, F. Bernaldo de Quirós and J. M. Maillo), 454-67, UNED, Santander.

Bischoff, J. L., and Fitzpatrick, J. A. 1991, U-series dating of impure carbonates: an isochron technique using total-sample dissolution, Geochimica et Cosmochimica Acta, 55(2), 543-54.

Bischoff, J. L., Shamp, D. D., Aramburu, A., Arsuaga, J. L., Carbonell, E., and Bermudez de Castro, J. M., 2003, The Sima de los Huesos Hominids date to beyond U/Th equilibrium ( $>350 \mathrm{kyr}$ ) and perhaps to $400-500 \mathrm{kyr}$ : new radiometric dates, Joumal of Archaeological Science, 30, 275-80.

Bischoff, J. L., Fitzpatrick, J. A., León, L., Arsuaga, J. L., Falgueres, C., Bahain, J. J., and Bullen, T., 1997, Geology and preliminary dating of the hominid-bearing sedimentary fill of the Sima de los Huesos Chamber, Cueva Mayor of the Sierra de Atapuerca, Burgos, Spain, Joumal of Human Evolution, 33(2-3), 129-54.

Bischoff, J. L., Ludwig, K., Garcia, J. F., Carbonell, E., Vaquero, M., Stafford, T. W., and Jull, A. J. T., 1994, Dating of the Basal Aurignacian Sandwich at Abric Romaní (Catalunya, Spain) by radiocarbon and uranium-series, Joumal of Archaeological Science, 21(4), 541-51.

Boëda, E., 1993, Le débitage discoide et le débitage Levallois récurrent centripète, Bulletin de la Société Préhistorique Française, 90(6), 392-404.

Boëda, E., 1994, Le concept Levallois: variabilité des méthodes, Monographie du CRA, vol. 9, 280 pp., CNRS éditions, Paris.

Bordes, F., 1961, Typologie du Paléolithique Inférieur et Moyen, Ed. Delmas, Bordeaux.

Bøtter-Jensen, L., Bulur, E., Duller, G. A. T., and Murray, A. S., 2000, Advances in luminescence instrument systems, Radiation Measurements, 32(5-6), 523-8.

Bronk-Ramsey, C., Higham, T., Bowles, A., and Hedges, R., 2004, Improvements to the pretreatment of bone at Oxford Radiocarbon, 46(1), 155-63.

Brown, T. A., Nelson, D. E., Vogel, J. S., and Southon, J. R., 1988, Improved collagen extraction by modified Longin method, Radiocarbon, 30(2), 171-7.

Condemi, S., 2003, Les Néandertaliens, in Anthropologie Biologique (eds. Ch. Sussane, E. Rebato and B. Chiarelli), 271-80, De Boeck, Bruxelles. 
Delibrias, G., 1985, Le carbone 14, in Méthodes de datations par les phénomènes nucleaires naturels (dir. E. Roth and B. Poty), 423-58, Masson, Paris.

Eggins, S., Grün, R., Pike, A. W. G., Shelley, M., and Taylor, L., 2003, 238U, 232Th profiling and U-series isotope analysis of fossil teeth by laser ablation-ICPMS, Quatemary Science Reviews, 22(10-13), 1373-82.

Eggins, S., Grün, R., McCulloch, M. T., Pike, A. W. G., Chappell, J., Kinsley, L., Mortimer, G., Shelley, M., Murray-Wallace, C. V., Spötl, C., and Taylor, L., 2005, In situ U-series dating by laser-ablation multi-collector ICPMS: new prospects for Quaternary geochronology, Quaternary Science Reviews, 24(23-24), $2523-38$.

Egocheaga, J. E., Trabazo, R., Rodríguez, L., Cabo, L. L., and Sierra, M. J., 2000, Avance sobre el descubrimiento, características del yacimiento y estudio paleoantropológico de los restos óseos de homínidos mesopleistocénicos de la Cueva de Sidrón (Piloña, Asturias), Bol. Cien. Nat. RIDEA, 46, 219-63.

Ford, D. G., and Schwarcz, H. P., 1981, Applications of stable isotope fractionation effects in waters, sedimentary deposits, flora and fauna, in Geomorphological techniques (ed. A. Goudie), 284-7, Allen \& Unwin, London.

Fortea, J., 2001, El Paleolítico Superior en Galicia y Asturias (1996-2000), XIV Congrès UISSP, 149-60.

Fortea, J., Rasilla, de la M., García-Tabernero, A., Gigli, E., Rosas, A., and Lalueza-Fox, C., 2008, Excavation protocol of bone remains for Neandertal DNA analysis in El Sidrón Cave (Asturias, Spain), Joumal of Human Evolution, $\mathbf{5 5}(2), 353-7$.

Fortea, J., Rasilla, de la M., Martínez, E., Sánchez-Moral, S., Cañaveras, J. C., Cuezva, S., Rosas, A., Soler, V., Julià, R., Torres, de T., Ortiz, J. E., Castro, J., Badal, E., Altuna, J., and Alonso, J., 2003, La Cueva de El Sidrón (Borines, Piloña, Asturias): Primeros resultados, Estudios Geológicos, 59, 159-79.

Gervilla, M., Beroiz, C., Barón, A., and Ramírez del Pozo, J., 1978, Memoria de la Hoja nº 29 (Oviedo) del Mapa Geológico Nacional (Magna) a escala 1:50.000, Instituto Geológico y Minero de España.

Goodfriend, G. A., 1991, Patterns of racemization and epimerization of amino acids in land snail shells over the course of the Holocene, Geochimica et Cosmochimica Acta, 55(1), 293-302.

Goodfriend, G. A., and Meyer, V. R., 1991, A comparative study of the kinetics of amino acid racemization/epimerization in fossil and modern mollusk shells, Geochimica et Cosmochimica Acta, 55(11), 3355-67.

Grandal-D'Anglade, A., and Vidal Romaní, J. R., 1997, A population study on the cave bear (Ursus spelaeus Ros.-Hein.)) from Cova Eirós (Triacastela, Galicia, Spain), Geobios, 30(5), 723-31.

Grün, R., 1995, Semi non-destructive, single aliquot ESR dating, Ancient TL, 13, 3-7.

Grün, R., 2002, ESR dose estimation on fossil tooth enamel by fitting the natural spectrum into the irradiated spectra, Radiation Measurements, 35(1), 87-93.

Grün, R., 2006, Direct dating of human remains, Yearbook of Physical Anthropology, 49, 2-48.

Grün, R., and Brumby, S., 1994, The assessment of errors in past radiation doses extrapolated from ESR/TL doseresponse data, Radiation Measurements, 23(2-3), 307-15.

Grün, R., and Katzenberger-Apel, O., 1994, An alpha irradiator for ESR dating, Ancient TL, 12, 35-8.

Grün, R., and McDermott, F., 1994, Open system modelling for U-series and ESR dating of teeth, Quaternary Science Reviews, 13(2), 121-5.

Grü, R., Beaumont, P., Tobias, P. V., and Eggins, S., 2003, On the age of Border Cave 5 human mandible, Journal of Human Evolution, 45(2), 155-67.

Higham, T. F. G., Jacobi, R. M., and Bronk Ramsey, C., 2006, AMS radiocarbon dating of ancient bone using ultrafiltration, Radiocarbon, $\mathbf{4 8}(2), 179-95$.

Horvatincic, N., Calic, R., and Geyh, M.A., 2000, Interglacial growth of tufa in Croatia, Quatemary Research, 53, $185-195$.

Hoyos, M., Sáenz de Buruaga, A., and Ormazabal, A., 1999, Cronoestratigrafía y paleoclimatología de los depósitos prehistóricos de la cueva de Arrillor (Araba, País Vasco), Munibe, 51, 137-51.

Ivanovich, M., and Harmon, R. S., 1992, Uranium series disequilibrium: applications to Earth, Marine and Environmental Sciences, Clarendon Press, Oxford.

Jöris, O., Álvarez Fernández, E., and Weninger, B., 2003, Radiocarbon evidence of the Middle to Upper Palaeolithic transition in southwestern Europe, Trabajos de Prehistoria, 60(2), 15-38.

Julià, R., and Bischoff, J. L., 1991, Radiometric dating of quaternary deposits and the hominid mandible of Lake Banyolas, Spain, Journal of Archaeological Science, 18(6), 707-22.

Krause, J., Lalueza-Fox, C., Orlando, L., Enard, W., Green, R. E., Burbano, H. A., Hublin, J.-J., Hanni, C., Fortea, J., Rasilla, M. d. 1., Bertranpetit, J., Rosas, A., and Paabo, S., 2007, The derived FOXP2 variant of modern humans was shared with Neandertals, Current Biology, 17, 1908-12.

Ku, T., and Liang, Z., 1984, The dating of impure carbonates with decay-series isotopes, Nuclear Instruments and Methods in Physics Research, 223(2-3), 563-71. 
Lalueza-Fox, C., Sampietro, M. L., Caramelli, D., Puder, Y., Lari, M., Calafell, F., Martinez-Maza, C., Bastir, M., Fortea, J., Rasilla, de la M., Bertranpetit, J., and Rosas, A., 2005, Neandertal evolutionary genetics: mitochondrial DNA data from the Iberian Peninsula, Molecular Biology and Evolution, 22(4), 1077-81.

Lalueza-Fox, C., Krause, J., Caramelli, D., Catalano, G., Milani, L., Sampietro, M. L., Calafell, F., Martinez-Maza, C., Bastir, M., Garcia-Tabernero, A., Rasilla, de la M., Fortea, J., Paabo, S., Bertranpetit, J., and Rosas, A., 2006, Mitochondrial DNA of an Iberian Neandertal suggests a population affinity with other European Neandertals, Current Biology, 16(16), R629-30.

Lalueza-Fox, C., Rompler, H., Caramelli, D., Staubert, C., Catalano, G., Hughes, D., Rohland, N., Pilli, E., Longo, L., Condemi, S., Rasilla, de la M., Fortea, J., Rosas, A., Stoneking, M., Schoneberg, T., Bertranpetit, J., and Hofreiter, M., 2007, A melanocortin 1 receptor allele suggests varying pigmentation among Neanderthals, Science, 318(5850), 1453-5.

Marsh, R. E., 1999, Beta-gradient isochrons using electron paramagnetic resonance: towards a new dating method in archaeology, McMaster University, Hamilton.

Martínez García, E., 1989, La Geología y el relieve de Asturias, in Enciclopedia Temática Asturiana, 57-124, Gijón.

Marzin, E., 1990, Essai de normalisation du protocole d'analyse des taux de racémisation des acides aminés: applications a la datation d'ossements fossiles, Travaux du LAPMO, VIII, 167-78.

Masters, P. M., 1986, Amino acid racemisation dating, in Dating and age determination of biological materials (eds. M. R. Zimmerman and J. L. Angel), 39-58, Croom Helm, London.

Murray, A. S., and Wintle, A. G., 2000, Luminescence dating of quartz using an improved single-aliquot regenerativedose protocol, Radiation Measurements, 32(1), 57-73.

Musgrave, J.H., 1973, The phalanges of Neanderthal and Upper Paleolithic hands, in Human evolution (ed. M. H. Day), 59-85, Taylor \& Francis, London.

Nelson, D. E., 1991, A new method for carbon isotopic analysis of protein, Science, 251, 552-4.

Ohtani, S., and Yamamoto, K., 1991, Age estimation using racemization of amino acid in human dentin, Joumal of Forensic Sciences, 36(3), 792-800.

Olejniczak, A. J., Smith, T. M., Feeney, R. N. M., Macchiarelli, R., Mazurier, A., Bondioli, L., Rosas, A., Fortea, J., Rasilla, de la M., Garcia-Tabernero, A., Radovcic, J., Skinner, M. M., Toussaint, M., and Hublin, J.-J., 2008, Dental tissue proportions and enamel thickness in Neandertal and modern human molars, Joumal of Human Evolution, 55(1), 12-23.

Poinar, H. N., Höss, M., Bada, J. L., and Pääbo, S., 1996, Amino acid racemization and the preservation of ancient DNA, Science, 272, 864-6.

Prieto, J. L., Abenza, J. M., Montes, R., Sanguino, J., and Muñoz, E., 2001, Hallazgos antropológicos y arqueológicos en el complejo kárstico de El Sidrón (Vallobal, Infiesto, Concejo de Piloña, Asturias), Munibe, 53, 19-29.

Rink, W. J., Schwarcz, H. P., Lee, H. K., Cabrera Valdes, V., Bernaldo de Quiros, F., and Hoyos, M., 1997, ESR dating of Mousterian levels at El Castillo Cave, Cantabria, Spain, Joumal of Archaeological Science, 24, 593-600.

Rosas, A., 2001, Occurrence of Neandertal features in mandibles from the Atapuerca-SH site, American Joumal of Physical Anthropology, 114, 74-91.

Rosas, A., and Aguirre, E., 1999, Restos humanos neandertales de la Cueva del Sidrón, Piloña, Asturias. Nota preliminar, Estudios Geológicos, 55, 181-91.

Rosas, A., Pena-Melian, A., Garcia-Tabernero, A., Bastir, M., Rasilla, de la M., and Fortea, J., 2008, Endocranial occipito-temporal anatomy of SD-1219 from the neandertal El Sidron site (Asturias, Spain), Anatomical RecordAdvances in Integrative Anatomy and Evolutionary Biology, 291(5), 502-12.

Rosas, A., Martinez-Maza, C., Bastir, M., Garcia-Tabernero, A., Lalueza-Fox, C., Huguet, R., Ortiz, J. E., Julia, R., Soler, V., Torres, de T., Martinez, E., Canaveras, J. C., Sanchez-Moral, S., Cuezva, S., Lario, J., Santamaria, D., Rasilla, de la M., and Fortea, J., 2006, Paleobiology and comparative morphology of a late Neandertal sample from El Sidron, Asturias, Spain, Proceedings of the National Academy of Science USA, 103, 19266-71.

Rosenbauer, R. J., 1991, UDATE1: a computer program for the calculation of uranium-series isotopic ages, Computers \& Geosciences, 17(1), 45-75.

Sánchez-Moral, S., Cañaveras, J. C., Lario, J., Cuezva, S., Silva, P. G., Rasilla, de la M., and Fortea, J., 2007, Caracterización del relleno sedimentario de la Galería del Osario (Cueva de El Sidrón, Asturias, España), in XII Reunión Nacional de Cuaternario (eds. J. Lario and P. G. Silva), 123-4, AEQUA, Ávila.

Santamaría, D., Forte, J., Rasilla, de la M., Martínez, L., Martínez, E., Cañaveras, J.C., Sánchez-Moral, S., Rosas, A., Estalrrich, A., García-Tabernero, A. and Lalueza-Fox, C., in press, The technological and typological behaviour of a Neanderthal group from El Sidrón cave (Asturias, Spain), Oxford Joumal of Archaeology.

Schwarcz, H. P., 1980, Absolute age determination of archeological sites by Uranium series dating of travertines, Archaeometry, 22, 3-24. 
Simpson, J. J., and Grün, R., 1998, Non-destructive gamma spectrometric U-series dating, Quaternary Science Reviews, 17(11), 1009-22.

Straus, L. G., and González Morales, M., 2003, El Mirón cave and the 14C chronology of Cantabrian Spain, Radiocarbon $\mathbf{4 5}(1), 41-58$

Tattersall, I., and Schwartz, J. H., 1998, Morphology, paleoanthropology, and Neanderthals, The Anatomical Record, 253, $113-17$.

Tisnérat-Laborde, N., Valladas, H., Kaltnecker, E., and Arnold, M., 2003, AMS radiocarbon dating of bones at LSCE, Radiocarbon, $\mathbf{4 3}, 3$.

Torres, T. de, García-Alonso, P., Canoira, L., and Llamas, J. F., 2000, Aspartic acid racemization and protein preservation in the dentine of European bear teeth, in Perspectives in amino acids and protein geochemistry (eds. M. J. C. G. A. Goodfriend, M. L. Fogel, S. A. Macko and J. F. Wehmiller), 349-55, Oxford University Press, New York.

Torres, T. de, Llamas, J. F., Canoira, L., and García-Alonso, P., 1999, Aspartic acid racemization in the dentine of bears (Ursus etruscus G. Cuvier, Ursus prearctos Boule, Ursus deningeri von Reichenau and Ursus spelaeus RosenmüllerHeinroth). Tooth dentine amino acids versus Mollusca amino acids, in Advances in biochirality (eds. G. Palyi, C. Zucchi and L. Caglioti), 247-56, Elsevier, Oxford.

Torres, T. de, Llamas, J. F., Canoira, L., García-Alonso, P., García-Cortés, A., and Mansilla, H., 1997, Amino acid chronology of the Lower Pleistocene deposits of Venta Micena (Orce, Granada, Andalusia, Spain), Organic Geochemistry, 26(1-2), 85-97.

Torres, T. de, Ortiz, J. E., Llamas, F. J., Canoira, L., Juliá, R., and García-Martínez, M. J., 2002, Bear dentine aspartic acid racemization analysis, proxy for pleistocene cave infills dating, Archeometry, 44(3), 417-26.

Torres, T. de, Ortiz, J. E., García, M. J., Llamas, F. J., Canoira, L., García de la Morena, M. A., and Julià, R., 2001, Geochemical evolution of amino acids in Pleistocene bears, Chirality, 13(8), 517-21.

Trinkaus, E., 1988, The evolutionary origins of the Neandertals or, why were there Neandertals?, in L'Homme de Neandertal. Vol 3. L'Anatomie, (ed. E. Trinkaus), 11-29, ERAUL 30, Liège.

Wolpoff, M. H., 1980, Paleoanthropology, Knopf, New York. 